\title{
Advances in the use of photoheterotrophic, mixotrophic and multi- trophic systems in marine shrimp farming
}

\author{
Laenne Barbara Silva de Moraes*, Débora Louise Barros Silva, Jéssika Lima de Abreu, Elizabeth Pereira \\ dos Santos, Renata da Sliva Farias, Luis Otávio Brito and Alfredo Olivera Gálvez
}

Aquaculture Departamento de Pesca e Aquicultura, Universidade Federal Rural de Pernambuco, Recife, PE, Brasil.

*Corresponding author: laennemoraes@gmail.com

\begin{abstract}
The growth of aquaculture can cause different environmental impacts, from the use of large amounts of water to the excessive release of effluent. Shrimp farming can be done in different systems: extensive, semi-intensive, intensive and super-intensive. Extensive systems with low productivity $\left(<500 \mathrm{~kg} \mathrm{ha}^{-1}\right.$ year $\left.^{-1}\right)$, exhibit low technological levels and less control of environmental conditions. The semi-intensive system requires food supplementation, reasonable natural productivity, biomas yield of 3,000 - 5,000 $\mathrm{kg} \mathrm{ha}^{-1}$ year-1 $^{-1}$ ) and water change (5 to $10 \%$ day $\left.^{-1}\right)$. To increase production, different culture systems are used, such as photoheterotrophic, heterotrophic and mixotrophic, with minimal water exchange $\left(0.5\right.$ to $3 \%$ day $\left.^{-1}\right)$, providing greater biomass yield (intensive 10 to 20 ton ha ${ }^{-1}$ cycle $^{-1}$ and super-intensive 20 up to 40 ton ha ${ }^{-1}$ cycle $^{-1}$ ). These can be developed in nursery or grow-out tanks, but with high operating costs, high technological levels, disease control and better control of environmental conditions. However, intensive and super-intensive systems accumulate nitrogen, phosphorus and solid waste that can be transformed into biomass in multi-trophic aquaculture systems. In this review, we will discuss the effects of these systems on water quality and productivity of marine shrimp. The photoheterotrophic, mixotrophic and multitrophic systems are interesting alternatives to the photoautotrophic systems in shrimp production, demonstrated by the higher zootechnical performance, as well as the environmental quality, since these models promote the minimum exchange of water and the transformation of nutrient residues in biomass.
\end{abstract}

Keywords: Aquaculture, Intensive system, Biofloc, Algae

\section{Introduction}

With declining fishing resources due to unsustainable fishing, fisheries production has been relatively stagnant since the 80's, making aquaculture an alternative to fish production. In 2016, according to data from FAO (2018), global aquaculture production reached 110.2 million tons, of which 7.9 million tons came from crustacean production.

Shrimp farming is one activity that is showing a significant development in several countries. In Brazil, it developed in the mid-70's when cultures started at experimental levels, but only in the 90's, the activity began to be economically viable (Rocha, 2011). The success of Brazilian shrimp farming was achieved with the introduction of the exotic species, Litopenaeus vannamei, native to the Pacific coast. This species has a high tolerance to environmental conditions such as temperature, $\mathrm{pH}$ and salinity among others. It has good zootechnical performance, and a well-developed technological package allowed a great boost to this activity (Vinatea-Arana, 2004).

In shrimp farming, culture can be grown in different systems: extensive, semi-intensive, intensive, and superintensive. Extensive systems are considered an important source of aquaculture production, especially in developing countries. In this system, maintaining water quality is essential for the development of the natural ecosystem, of primary (photoautotrophic) and secondary producers, that are a source of crustacean live food (Tacon et al., 2004; Wasielesky et al., 2006). They are developed with low biomass ( $<500 \mathrm{~kg} \mathrm{ha}^{-1}$ year-1 $\left.^{-1}\right)$, being able to support animals with little aeration, presenting low operating costs, low technological levels, without controlling diseases and environmental conditions (Southgate and Lucas, 2019).

The semi-intensive system is between extensive and intensive cultivation, requires food supplementation, but still depends on natural productivity, with biomass production of 3,000 to $5,000 \mathrm{~kg} \mathrm{ha}^{-1}$ year-1 and water renewal of $5-10 \%$ per day $^{-1}$, presenting low operating costs, intermediate technological levels, intermediate control of environmental conditions and greater spread of diseases (Southgate and Lucas, 2019). In this system, most of the nutrients originated from formulated diets, thus feeding strategies must be optimized considering the chemical fluxes, water quality and shrimp production (Casillas-Hernández et al., 2007).

In intensive and super-intensive systems all the nutrients for the farmed stock come from introduced feeds, requiring highly balanced diet and providing higher yields per unit area or volume (intensive 10 to 20 ton ha- $^{-1} \mathrm{cycle}^{-1}$ and super-intensive 20 to 40 ton $\mathrm{ha}^{-1}$ cycle $^{-1}$ ), with minimal exchange of water ( 0.5 to $3 \%$ day $^{-1}$ ) (Avnimelech, 2009). The stocking density depends upon being able to maintain the water quality conditions required by the organism, in the shrimp culture the biomass could be 1 to $2 \mathrm{~kg} \mathrm{~m}^{-3}$ (Avnimelech, 2009; Southgate and Lucas, 2019). These 
systems can be developed in nursery or grow-out tanks, presenting high operating costs, high technological levels, high energy inputs (power, aeration, filtration, pumping), without energy recycling, low energy losses with feeding and disease control and environmental conditions (Southgate and Lucas, 2019).

However, in recent years, with the aim of reducing the environmental and economic impacts generated by the activity, studies have been initiated using other types of culture methods with minimal water exchange. These systems can be classified as heterotrophic, photoheterotrophic and mixotrophic, according to the energy sources used by the producing organisms. The heterotrophic system is characterized by the use of organic compounds as an energy source in the absence of light, being classified as photoheterotrophic when it occurs in the presence of light, while the mixotrophic system is characterized by the use of light, inorganic and organic compounds as energy sources (Pérez-García and Bashan, 2015). Combined or not with these systems is the use of the multi-trophic system, where species of different trophic levels take advantage, as a source of energy, compounds that would be rendered useless by cultivating only a single species (Troell et al., 2009).

\section{Photoautotrophic (algal based systems)}

Algal based systems, also known as traditional or conventional culture systems, usually built on land, consist of culture systems that have as primary base the development of systems based on phytoplankton. These are photosynthetic microorganisms that absorb carbon dioxide and supply oxygen from nutrient assimilation. They play an important role in the water quality of the system where the dynamics of oxygen production and nutrient cycle occurs but maintains a balance between photosynthetic activity and cellular respiration, varying seasonally due to temperature, light, and concentration of these nutrients in the substrate (Hargreaves, 2006). In such systems, the phosphorus and nitrogen are the most important limiting nutrients. The development of phytoplankton may require concentrations of 0.01 to $0.1 \mathrm{mg} \mathrm{L}^{-1}$ soluble inorganic phosphorus and 0.1 to $0.75 \mathrm{mg} \mathrm{L}^{-1}$ inorganic nitrogen (Boyd, 2015).

Phytoplanktons, represented by microalgae, have a rich species diversity and are adapted to different environments, including freshwater, saltwater or even the sediment (Nigam and Singh, 2011). They also have the abilities of rapid multiplication and increasing the biomass (Martínez-Córdova et al., 2015). In addition to the important role played in the water quality of photoautotrophic systems, the phytoplankton is also a nutritional source for cultured animals, since it is rich in lipids, carbohydrates, vitamins, pigments, and minerals, whose content varies according to species (Abdelnour et al., 2019; Sahni et al., 2019).
Phytoplankton production is mainly stimulated through system fertilization, such as the use of agricultural residues or inorganic and mineral fertilizers, which also contribute to the development of zooplankton and benthic species that can be directly consumed by farmed animals (Hargreaves, 2006). Swine, cattle, and poultry waste are are the commonly used organic manures (Martínez-Córdova et al., 2015), constituting sources of Carbon (C), Nitrogen (N), and Phosphorus (P), but this organic material can be nutritionally inadequate and unpalatable to the animals.

When only chemical (inorganic) fertilizers are used, carbon is derived from photosynthetic processes (Boyd and Tucker, 1998), which is highly recommended. Inorganic fertilizers commonly used in agricultural crops include urea, sodium nitrate, ammonium nitrate, triple superphosphate, and ammonium phosphate (Lin et al., 1997). As for the ratio of nitrogen and phosphorus (N:P), this can be established between 5:1 and 10:1, varying with site specificities (Boyd, 1997). According to Biró (1995) the optimal amount of fertilizer addition depends on water and soil characteristics, and for organic fertilizer amounts are around $100-200 \mathrm{~kg}$ $\mathrm{ha}^{-1}$. As for the inorganic fertilizer, Lin et al. (1997) considers the application rate of $28-56 \mathrm{~kg} \mathrm{ha}^{-1}$ of $\mathrm{N}$ and $7-14 \mathrm{~kg} \mathrm{ha}^{-1}$ of $\mathrm{P}$, often every two weeks. In practice, the ponds are usually treated with liming materials to reduce acidity, increase total alkalinity and improve the system's fertilization response (Diana et al., 1997).

Phytoplankton biomass can also be generated by assimilating unconsumed nutrients from inert feed and animal excretion (Martínez-Córdova et al., 2015). Fertilizer use should be established at appropriate levels as dense phytoplankton limit light penetration in water (Schroeder, 1978), and the seasonal variation of these organisms due to environmental conditions and ecological successions is emphasized. Its presence highly depends on aquaculture type, intensification level, cultivated species, and food management practices (Moriarty, 1997).

Phytoplankton is distributed among the Cyanophyta, Chlorophyta, Heterokontophyta, Pyrrophyta and Euglenophyta divisions. The "blooms" give the water its characteristic color, and the highest growth rates usually occur during spring and summer and are slower in colder periods (Boyd, 2015). The presence of diatoms (Heterokontophyta) and green algae (Chlorophyta) is considered desirable, especially for the feeding of most aquatic invertebrates, and fish and shrimp larvae. When growing in outdoor farms with enough light and natural photoperiod, it may be the dominant community (Yusoff et al., 2002; Godoy et al., 2012). The presence of cyanobacteria (Cyanophyta) and dinoflagellates (Pyrrophyta) reflects poor water quality and eutrophication, where a reduction in diatom populations can be observed under these conditions (Yusoff et al., 2002). The presence of these two groups is considered undesirable due to toxin production and taste alteration, besides their potential to generate mortality in the culture (Boyd, 2015; Souza et al., 2012). 
Conventional culture can be developed in different production systems. When established in still water it presents low yield, with less than $10 \mathrm{pl} \mathrm{m}^{-2}$, equivalent to the

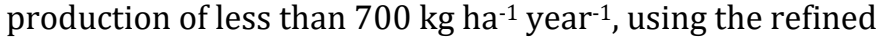
feed, whose residues can be assimilated by natural recycling (Joffre et al., 2018). As the stocking density of shrimp and the shrimp biomass increase, more feed is used, generating an increase in the production of metabolites such as carbon, nitrogen and phosphorus, because $75 \%$ of $\mathrm{N}$ and $\mathrm{P}$ are not used and these remain as residues in water. This requires high water exchange rates (5-20\%) because phytoplankton have a limited rate of carbon assimilation in such ponds, on the order of 2 - $10 \mathrm{~g}$ of carbon / $\mathrm{m}^{2}$ per day (Avnimelech, 2009). Thus, to control waste, this effluent is released into adjacent water bodies. Some studies have shown improved shrimp zootechnical performance with exchange of water (Green et al., 1999; Mohanty et al., 2015). However, these nutrient loads (N, P and organic carbon) were equivalent to
$6.79-71.9 \mathrm{~kg}$ of inorganic $\mathrm{N}, 0.63-14.3 \mathrm{~kg}$ of $\mathrm{P}$ and $13.04 \mathrm{~kg}$ of total OC per ton of shrimp (Sahu et al., 2013; Boyd and Queiroz, 2001; Jackson et al. 2003).

In traditional semi-intensive culture system, with densities of $10-29$ shrimp $\mathrm{m}^{-2}$ and production of 3.5 tons ha-1 $^{-1}$ ciclo-1 $^{-1}$ (Table 1), nutrition and good zootechnical performance results become dependent on diet supplementation with inert food (Martínez-Cordova et al., 2015; Joffre et al., 2018). In the case of penaeid, Nunes et al. (1997) estimated that $29.7 \%$ of the carbon present in shrimp muscle comes from inert food and the others from natural productivity, highlighting the importance of its establishment in aquaculture. In intensive culture, especially shrimp larviculture, there is also a predominance of photoautotrophic conditions, because microalgae rich in polyunsaturated fatty acids are daily addition (Lorenzo et al., 2015).

Table 1. Zootechnical performance of marine shrimp reared in photoautotrophic systems (algal based systems).

\begin{tabular}{|c|c|c|c|c|c|c|c|}
\hline Shrimp specie & Phase & $\begin{array}{c}\text { Stocking } \\
\text { density } \\
\text { (shrimp) }\end{array}$ & Yield & $\begin{array}{c}\text { Final } \\
\text { weight } \\
\text { (g) }\end{array}$ & $\begin{array}{c}\text { Survival } \\
(\%)\end{array}$ & $\begin{array}{c}\text { Time } \\
\text { (days) }\end{array}$ & Reference \\
\hline L. vannamei & $\mathrm{N}$ & $108 \mathrm{~m}^{-2}$ & $0.095 \mathrm{~kg} \mathrm{~m}^{-2}$ & 1.20 & 73.3 & 32 & Ogle (1992) \\
\hline P. monodon & $\mathrm{N}$ & $288 \mathrm{~m}^{-3}$ & $0.218 \mathrm{~kg} \mathrm{~m}^{-3}$ & 0.78 & 97 & 30 & Rodriguez et al. (1993) \\
\hline L. vannamei & $\mathrm{N}$ & $1,521 \mathrm{~m}^{-3}$ & $2.699 \mathrm{~kg} \mathrm{~m}^{-3}$ & 1.9 & 93.4 & 42 & Otoshi et al. (2001) \\
\hline P. semisulcatus & $\mathrm{N}$ & $180 \mathrm{~m}^{-3}$ & $0.111 \mathrm{~kg} \mathrm{~m}^{-3}$ & 0.67 & 77.4 & 35 & Nour et al. (2004) \\
\hline L. vannamei & $\mathrm{N}$ & $6,250 \mathrm{~m}^{-3}$ & $2.408 \mathrm{~kg} \mathrm{~m}^{-3}$ & 0.428 & 90 & 42 & Silva et al. (2009) \\
\hline L. vannamei & $\mathrm{N}$ & $250 \mathrm{~m}^{-3}$ & $0.475 \mathrm{~kg} \mathrm{~m}^{-3}$ & 0.87 & 68.0 & 63 & Becerra-Dorame et al. (2012) \\
\hline L. schimitti & $\mathrm{N}$ & $50 \mathrm{~m}^{-2}$ & $0.244 \mathrm{~kg} \mathrm{~m}^{-3}$ & 5.38 & 90.8 & 105 & Márquez et al. (2012) \\
\hline L. vannamei & $\mathrm{N}$ & $1,500 \mathrm{~m}^{-3}$ & $0.378 \mathrm{~kg} \mathrm{~m}^{-3}$ & - & 60 & 30 & Supono et al. (2014) \\
\hline L. vannamei & $\mathrm{N}$ & $1,100 \mathrm{~m}^{-3}$ & $0.719 \mathrm{~kg} \mathrm{~m}^{-3}$ & 0.82 & 79.7 & 20 & Lara et al. (2016) \\
\hline L. vannamei & $\mathrm{N}$ & $67,000 \mathrm{~m}^{-3}$ & $0.07 \mathrm{~kg} \mathrm{~m}^{-3}$ & 0.0014 & 94.4 & 13 & Schveitzer et al. (2017) \\
\hline L. vannamei & G & $10 \mathrm{~m}^{-2}$ & $0.130 \mathrm{~kg} \mathrm{~m}^{-3}$ & 18.1 & 72 & 77 & Wyban et al. (1987) \\
\hline L. vannamei & G & $20 \mathrm{~m}^{-2}$ & $0.126 \mathrm{~kg} \mathrm{~m}^{-3}$ & 9.69 & 65 & 84 & Freeman et al. (1992) \\
\hline L. vannamei & G & $30 \mathrm{~m}^{-2}$ & $0.334 \mathrm{~kg} \mathrm{~m}^{-3}$ & 15.97 & 69.8 & 133 & Martinez-Cordova et al. (1998) \\
\hline L. vannamei & G & $16 \mathrm{~m}^{-2}$ & $0.179 \mathrm{~kg} \mathrm{~m}^{-3}$ & 12.93 & 88.8 & 112 & Martinez-Cordova et al. (2002) \\
\hline P.monodon & G & $25 \mathrm{~m}^{-2}$ & $0.424 \mathrm{~kg} \mathrm{~m}^{-3}$ & 16.8 & 84 & 56 & Smith et al. (2002) \\
\hline L. vannamei & G & $15 \mathrm{~m}^{-2}$ & $0.181 \mathrm{~kg} \mathrm{~m}^{-3}$ & 12.52 & 96.6 & 102 & Peixoto Jr et al. (2003) \\
\hline F. paulensis & G & $15 \mathrm{~m}^{-2}$ & $0.148 \mathrm{~kg} \mathrm{~m}^{-3}$ & 11.17 & 88.3 & 102 & Peixoto Jr et al. (2003) \\
\hline L. vannamei & G & $35 \mathrm{~m}^{-2}$ & $0.207 \mathrm{~kg} \mathrm{~m}^{-3}$ & 8.5 & 69.7 & 131 & Brito et al. (2006) \\
\hline L. vannamei & G & $37.5 \mathrm{~m}^{-2}$ & $0.445 \mathrm{~kg} \mathrm{~m}^{-3}$ & 12.29 & 96.7 & 88 & Silva et al. (2008) \\
\hline F. subtilis & G & $16 \mathrm{~m}^{-2}$ & $0.124 \mathrm{~kg} \mathrm{~m}^{-3}$ & 8.49 & 91.7 & 87 & Souza et al. (2009) \\
\hline
\end{tabular}

N: Nursery phase; G: Grow-out phase.

Despite the emphasis on the importance of phytoplankton domain in this system, there are certain disadvantages present in the photoautotrophic condition, such as diurnal variations in $\mathrm{pH}$, ammonia and oxygen levels, mainly due to bloom (Burford et al., 2003; Ebeling et al., 2006). There is a net increase in dissolved oxygen and a net reduction in carbon dioxide during the day and vice versa at night, becoming a stressor, causing mortality as a result of the formation of oxygen-free layers and accumulation of toxic compounds such as ammonia, nitrite and hydrogen sulfide (Yusoff et al., 2002). The greater the abundance of phytoplankton, the greater the magnitude of the daily variation of these factors (Boyd, 2015). Therefore, adequate management of the system is recommended, especially in water quality and control of the phytoplankton community (Souza et al., 2012). Measurements for phytoplankton abundance evaluation can be done through microscopic analysis or indirect methods such as determination of particulate organic matter, chlorophyll $a$ and Secchi disc analysis (Boyd, 2015). This control can lead to improved growth, optimizing productivity and financial return for farms (Moriarty, 1997). 


\section{Photoheterotrophic System}

Photoheterotrophic systems are characterized by the use of organic compounds and light as energy sources (PérezGarcía and Bashan, 2015). Among the variations of this type of culture is the biofloc system (BFT). Studies on BFT were initiated in the 70's by Ifremer - COP (French Research Institute for Sea Exploration, Pacific Ocean Center), where different species of marine shrimp such as Litopenaeus stylirostris and L. vannamei were examined (Hopkins, 1994; Emerenciano et al., 2013b). Already in the 80's, Ifremer started a French scientific program called "Ecotron" to better understand the system (Serfling, 2006). Several studies have contributed to a comprehensive approach to the biofloc system and clarified the interrelationships within the system, such as water and bacteria, as well as nutrition and physiology (Avnimelech, 2007). Already in the late 80's and early 90's, USA (Waddell Mariculture Center) and Israel conducted research with the biofloc system using $L$. vannamei and Tilapia, respectively, and the main motivations for starting studies were limitation costs, land acquisition costs, and concerns about environmental impact (Serfling, 2006; Avnimelech, 2009).

The biofloc system is a super-intensive system with high stocking densities (300 to 1500 shrimp $\mathrm{m}^{-2}$ ) where the strong aeration and zero or minimal water exchange make possible the formation of microbial floc. The development of the system occurs through the manipulation of the carbon: nitrogen ratio (C:N) in the cultivation environment, thus stimulating the growth of a microbial community, where the floc is formed by a heterogeneous mixture of bacteria, phytoplankton, zooplankton, remains of food and feces, exoskeletons and other invertebrates, predominantly the heterotrophic and aerobic biota (De Schryver et al., 2008; Avnimelech, 2009; Samocha et al., 2017). The floc formed in the system has a high protein content (Khatoon et al., 2016), which can be an alternative food for the organisms, improving the zootechnical performance and decreasing the feed conversion rate (Avnimelech, 2009).

This culture system can be implemented in small areas, favoring the good use of the area and greater productive efficiency, since one of the obstacles to the development of aquaculture is the availability and cost of the land. In addition to the low use of water, it is feasible to construct cultivation units both near and far from the coastline, enabling the interiorization of farms using low salinity waters (Samocha et al., 2012). Another advantage presented by the system is the possibility of reusing water for several production cycles without a negative impact on crop yield (Krummenauer et al., 2014).

The biofloc system was developed mainly to control the nitrogenous compounds (ammonia) that accumulate and when in high concentrations, they are toxic to aquaculture organisms (Avnimelech et al., 2007). The main nitrogen cycling processes in closed culture systems are made by microalgae that absorb nitrogen and bacteria responsible for the nitrification process (Hargreaves, 1998). The heterotrophic bacteria present in the biofloc system can also act on nitrogen removal in water, both organic (free and combined amino acids) and inorganic (ammonia and nitrate) forms, in addition to being involved in the decomposition process (Wheeler and Kirchman, 1986).

However, in order for bacteria to be able to synthesize organic carbon from proteins and ammonia, it is necessary that $\mathrm{C}: \mathrm{N}$ ratio is suitable in the water for use, as they do not have good efficiency in decomposing organic material when there are high levels of carbon or nitrogen. With a $\mathrm{C}: \mathrm{N}$ ratio of approximately 10-20:1 (weight-based ratio) digestion is relatively easy (Chamberlain et al., 2001; Hargreaves et al., 2006; De Schryver et al., 2008; Avnimelech, 2009).

The stabilization of bacteria in the biofloc system can be divided into two phases: In the first, there is a predominance of heterotrophic bacteria in the system. This is because they are fast-growing, and in the second phase there is a predominance of autotrophic bacteria, as they have slower growth (Avnimelech, 2009). The autotrophic bacteria begin to stabilize between 2 nd and 3rd weeks after the carbon source introduction (Wasielesky et al., 2013). These bacteria work in the system, converting nitrogen compounds to nitrate (Krummnenauer et al., 2014).

According to Wasielesky et al. (2006), the presence of bacteria at the beginning of culture is of great importance in preventing the development and competition for the substrate with the bacteria responsible for ammonia oxidation. Bacteria responsible for the oxidation of ammonia to nitrite, a highly toxic compound, may cause harm to the producer by reducing animal growth and increasing mortality. The complexity and dynamics of this system require intensive management and should always be aware of the physicochemical and biological parameters of water (Wasielesky et al., 2006).

Several studies related to this type of system have been carried out in the last years, aiming to improve the zootechnical performance of the culture animals, as well as to better understand the functioning of the system. Brito et al. (2015) got satisfactory results when post-larvae of $L$. vannamei were cultured in a biofloc system in terms of the zootechnical performance of the animals with the average final weight of $0.68 \mathrm{~g}$; the survival was $71.3 \%$ and yield was $1.21 \mathrm{~kg} \mathrm{~m}^{-3}$ for 35 days of culture. Marinho et al. (2014) cultured the post-larvae of the same species and obtained a final weight of $0.24 \mathrm{~g}, 41.5 \%$ of survival and weight gain of $0.22 \mathrm{~g}$, at 20 days of culture. Abreu et al. (2019) also had good zootechnical results for post-larvae of L. vannamei cultured in the biofloc system, which reached a final average weight of $0.69 \mathrm{~g}$, survival $93 \%$ and yield of $1.95 \mathrm{~kg} \mathrm{~m}^{-3}$, in 42 days of culture (Table 2). 
Table 2. Zootechnical performance of marine shrimp reared in photoheterotrophic systems.

\begin{tabular}{|c|c|c|c|c|c|c|c|}
\hline Shrimp specie & Phase & $\begin{array}{c}\text { Stocking } \\
\text { density } \\
\text { (shrimp) }\end{array}$ & Yield & $\begin{array}{c}\text { Final } \\
\text { weight } \\
\text { (g) }\end{array}$ & $\begin{array}{c}\text { Survival } \\
(\%)\end{array}$ & $\begin{array}{c}\text { Time } \\
\text { (days) }\end{array}$ & Reference \\
\hline F. brasiliensis & $\mathrm{N}$ & $500 \mathrm{~m}^{-2}$ & $0.15 \mathrm{~kg} \mathrm{~m}^{-2}$ & 0.3 & 94 & 30 & Fóes et al. (2011) \\
\hline F. brasiliensis & $\mathrm{N}$ & $1000 \mathrm{~m}^{-3}$ & $0.02 \mathrm{~kg} \mathrm{~m}^{-3}$ & 0.24 & 67 & 30 & Emerenciano et al. (2012) \\
\hline L. vannamei & $\mathrm{N}$ & $1500 \mathrm{~m}^{-2}$ & $0.65 \mathrm{~kg} \mathrm{~m}^{-2}$ & 0.45 & 96.3 & 30 & Wasielesky et al. (2013) \\
\hline L. vannamei & $\mathrm{N}$ & $2500 \mathrm{~m}^{-3}$ & $0.25 \mathrm{~kg} \mathrm{~m}^{-3}$ & 0.24 & 41.5 & 20 & Marinho et al. (2014) \\
\hline L. vannamei & $\mathrm{N}$ & $250 \mathrm{~m}^{-3}$ & $3.22 \mathrm{~kg} \mathrm{~m}^{-3}$ & 14.47 & 89.2 & 49 & Jatobá et al. (2014) \\
\hline F. brasiliensis & $\mathrm{N}$ & $750 \mathrm{~m}^{-3}$ & $0.622 \mathrm{~kg} \mathrm{~m}^{-3}$ & 1.03 & 80.5 & 30 & Souza et al. (2014) \\
\hline L. vannamei & $\mathrm{N}$ & $2500 \mathrm{~m}^{-3}$ & $1.21 \mathrm{~kg} \mathrm{~m}^{-3}$ & 0.68 & 71.3 & 35 & Brito et al. (2015) \\
\hline L. vannamei & $\mathrm{N}$ & $1200 \mathrm{~m}^{-2}$ & $1.44 \mathrm{~kg} \mathrm{~m}^{-2}$ & 1.22 & 98.6 & 35 & Serra et al. (2015) \\
\hline L. vannamei & $\mathrm{N}$ & $2500 \mathrm{~m}^{-3}$ & $0.46 \mathrm{~kg} \mathrm{~m}^{-3}$ & 0.205 & 91.3 & 20 & Marinho et al. (2017) \\
\hline L. vannamei & $\mathrm{N}$ & $3000 \mathrm{~m}^{-3}$ & $1.95 \mathrm{~kg} \mathrm{~m}^{-3}$ & 0.69 & 93.6 & 42 & Abreu et al. (2019) \\
\hline F. duorarum & G & $38 \mathrm{~m}^{-2}$ & $0.32 \mathrm{~kg} \mathrm{~m}^{-2}$ & 13.3 & 63 & 210 & Emerenciano et al. (2013a) \\
\hline L. vannamei & G & $238 \mathrm{~m}^{-3}$ & $1.0 \mathrm{~kg} \mathrm{~m}^{-3}$ & 6.2 & 70.6 & 34 & Schveitzer et al. (2013) \\
\hline L. vannamei & G & $300 \mathrm{~m}^{-2}$ & $0.586 \mathrm{~kg} \mathrm{~m}^{-2}$ & 2.17 & 90 & 42 & Silva et al. (2013) \\
\hline P. monodon & G & $21 \mathrm{~m}^{-3}$ & $0.132 \mathrm{~kg} \mathrm{~m}^{-3}$ & 6.6 & 95 & 60 & Anand et al. (2014) \\
\hline L. vannamei & G & $425 \mathrm{~m}^{-3}$ & $1.30 \mathrm{~kg} \mathrm{~m}^{-3}$ & 5.42 & 56 & 28 & Brito et al. (2014a) \\
\hline P. monodon & G & $100 \mathrm{~m}^{-3}$ & $0.622 \mathrm{~kg} \mathrm{~m}^{-3}$ & 7.5 & 83 & 75 & Kumar et al. (2015) \\
\hline L. vannamei & G & $130 \mathrm{~m}^{-3}$ & $0.674 \mathrm{~kg} \mathrm{~m}^{-2}$ & 5.97 & 86.9 & 60 & Rajkumar et al. (2016) \\
\hline L. vannamei & G & $300 \mathrm{~m}^{-3}$ & $2.83 \mathrm{~kg} \mathrm{~m}^{-3}$ & 9.99 & 95.5 & 42 & Xu et al. (2016) \\
\hline L. vannamei & G & $250 \mathrm{~m}^{-3}$ & $1.7 \mathrm{~kg} \mathrm{~m}^{-3}$ & 11.1 & 69 & 55 & Ray et al. (2017) \\
\hline L. vannamei & G & $300 \mathrm{~m}^{-3}$ & $2.48 \mathrm{~kg} \mathrm{~m}^{-3}$ & 8.75 & 96.7 & 35 & Xu et al. (2018) \\
\hline
\end{tabular}

N: Nursery phase; G: Grow-out phase.

Table 3. Zootechnical performance of marine shrimp reared in mixotrophic systems.

\begin{tabular}{|c|c|c|c|c|c|c|c|}
\hline Shrimp specie & Phase & $\begin{array}{c}\text { Stocking } \\
\text { density } \\
\text { (shrimp) }\end{array}$ & Yield & $\begin{array}{c}\text { Final } \\
\text { weight } \\
\text { (g) }\end{array}$ & $\begin{array}{c}\text { Survival } \\
(\%)\end{array}$ & $\begin{array}{c}\text { Time } \\
\text { (days) }\end{array}$ & Reference \\
\hline F. paulensis & $\mathrm{N}$ & $300 \mathrm{~m}^{-2}$ & $0.206 \mathrm{~kg} \mathrm{~m}^{-2}$ & 0.72 & 95.4 & 30 & Ballester et al. (2007) \\
\hline P. monodon & $\mathrm{N}$ & $40,000 \mathrm{~m}^{-3}$ & - & - & 56.3 & 19 & Khatoon et al. (2009) \\
\hline F. paulensis & $\mathrm{N}$ & $250 \mathrm{~m}^{-2}$ & $0.151 \mathrm{~kg} \mathrm{~m}^{-2}$ & 0.68 & 89 & 45 & Ballester et al. (2010) \\
\hline F. paulensis & $\mathrm{N}$ & $10,000 \mathrm{~m}^{-3}$ & $0.325 \mathrm{~kg} \mathrm{~m}^{-3}$ & 0.068 & 47.8 & 15 & Emerenciano et. al 2011 \\
\hline L. vannamei & $\mathrm{N}$ & $1000 \mathrm{~m}^{-3}$ & $1.077 \mathrm{~kg} \mathrm{~m}^{-3}$ & 1.11 & 97 & 43 & Godoy et al., 2012 \\
\hline L. vannamei & $\mathrm{N}$ & $2500 \mathrm{~m}^{-3}$ & $0.84 \mathrm{~kg} \mathrm{~m}^{-3}$ & 0.348 & 96 & 20 & Marinho et al., 2014 \\
\hline L. vannamei & $\mathrm{N}$ & $390 \mathrm{~m}^{-2}$ & $0.943 \mathrm{~kg} \mathrm{~m}^{-2}$ & 2.43 & 99.5 & 30 & Martins et al., 2014 \\
\hline L. vannamei & $\mathrm{N}$ & $2500 \mathrm{~m}^{-3}$ & $2.46 \mathrm{~kg} \mathrm{~m}^{-3}$ & 1.08 & 91.7 & 35 & Brito et al., 2015 \\
\hline L. vannamei & $\mathrm{N}$ & $2500 \mathrm{~m}^{-3}$ & $0.67 \mathrm{~kg} \mathrm{~m}^{-3}$ & 0.27 & 98.3 & 20 & Marinho et al., 2017 \\
\hline L. vannamei & $\mathrm{N}$ & $3000 \mathrm{~m}^{-3}$ & $2.42 \mathrm{~kg} \mathrm{~m}^{-3}$ & 0.86 & 93.6 & 42 & Abreu et al., 2019 \\
\hline L. stylirostris & $\mathrm{G}$ & $20 \mathrm{~m}^{-2}$ & $1,886 \mathrm{~kg} \mathrm{ha}^{-1}$ & 15.16 & 66.5 & 140 & Cordova et al., 2002 \\
\hline L. vannamei & G & $130 \mathrm{~m}^{-2}$ & $21,001 \mathrm{~kg} \mathrm{ha}^{-1}$ & 18.4 & 88 & 90 & Taw \& Chandaeng, 2005 \\
\hline L. vannamei & $\mathrm{G}$ & $550 \mathrm{~m}^{-2}$ & $51,893 \mathrm{~kg} \mathrm{ha}^{-1}$ & 13.8 & 66 & 57 & Taw \& Chandaeng, 2005 \\
\hline P. monodon & $\mathrm{G}$ & $5000 \mathrm{~m}^{-3}$ & $1.11 \mathrm{~kg} \mathrm{~m}^{-3}$ & 0.9 & 60.6 & 49 & Arnold et al., 2009 \\
\hline L. vannamei & $\mathrm{G}$ & $115 \mathrm{~m}^{-2}$ & $16,300 \mathrm{~kg} \mathrm{ha}^{-1}$ & 16.7 & 85 & 113 & Avnimelech et al., 2009 \\
\hline L. vannamei & $\mathrm{G}$ & $403 \mathrm{~m}^{-3}$ & $9.59 \mathrm{~kg} \mathrm{~m}^{-3}$ & 25.22 & 94 & 38 & Samocha et al., 2010 \\
\hline L. vannamei & $\mathrm{G}$ & $130 \mathrm{~m}^{-2}$ & $22,514 \mathrm{~kg} \mathrm{ha}^{-1}$ & 18.78 & 89.2 & 90 & Taw et al., 2011 \\
\hline F. paulensis & $\mathrm{G}$ & $60 \mathrm{~m}^{-2}$ & $0.287 \mathrm{~kg} \mathrm{~m}^{-2}$ & 5.98 & 93.3 & 75 & Wasielesky Jr et al., 2012 \\
\hline L. vannamei & G & $224 \mathrm{~m}^{-3}$ & $2.219 \mathrm{~kg} \mathrm{~m}^{-3}$ & 10.70 & 92.6 & 30 & Xu \& Pan, 2014 \\
\hline L. vannamei & $\mathrm{G}$ & $300 \mathrm{~m}^{-3}$ & $2.81 \mathrm{~kg} \mathrm{~m}^{-3}$ & 9.84 & 97.3 & 42 & Xu et al., 2016 \\
\hline
\end{tabular}

$\mathrm{N}$ : Nursery phase; G: Grow-out phase. 


\section{Mixotrophic system}

The mixotrophic system is a variant of the heterotrophic and photoautotrophic while using light and organic compounds as energy sources, and both respiratory and photosynthetic metabolism operating concurrently (Perez-García and Bashan, 2015). This type of system has been widely used in aquaculture, whether for the cultivation of microalgae, crustaceans or fish, with good yield results (Perez-García and Bashan, 2015; Brito et al., 2015).

Shrimp culture using biofloc technology in mixotrophic system had been reported to have achieved better growth rates, yield, and FCR, benefitting from microalgae dominance (Marinho et al., 2014; Marinho et al., 2017), association of microalgae and rotifers (Brito et al., 2015) or bacteria (Xu et al., 2016). The addition of microalgae contributes to the good performance of Litopenaeus vannamei when cultured in the biofloc system, as shown by Marinho et al. $(2014,2017)$. When added to microalgae Navicula sp., a final weight of $0.348 \mathrm{~g}$, yield of $0.84 \mathrm{~kg} \mathrm{~m}^{-3}$ and FCR of 0.9 after 20 days of culture were achieved, while the addition of three diatom species (Chaetoceros calcitrans, Navicula sp. and Phaeodactylum tricornutum) resulted in a final weight of $0.27 \mathrm{~g}$, yield of 0.67 $\mathrm{kg} \mathrm{m}^{-3}$ and FCR of 0.61 . Values higher than the treatment without the addition of microalgae amounting to a final weight of 0.27 and $0.18 \mathrm{~g}$, yield of 0.63 and $0.59 \mathrm{~kg} \mathrm{~m}^{-3}$ and FCR of 0.64 and 1.2 were obtained for both the experiments, respectively (Table 3). Because of the good results with Navicula, research was carried out with the different concentrations of this microalga: 25,000, 50,000 and 100,000 cells $\mathrm{mL}^{-1}$, where it was verified that concentrations of 50,000 and 100,000 cells mL $^{-1}$ achieved the best results for the final weight ( 0.80 and $0.86 \mathrm{~g}$, respectively) and the SGR (15.92 and $16.08 \%$ day $^{-1}$, respectively), but all the treatments had good results with Navicula, with a yield of 2.19 to $2.42 \mathrm{~kg} \mathrm{~m}^{-3}$ and FCR of 0.77 to 0.82 (Abreu et al., 2019). In addition, it is also observed that the diatoms, $C$. calcitrans and $P$. tricornutum, were outside the biofloc while the Navicula sp. was part of biofloc (Marinho et al., 2017). Abreu et al. (2019) found that biofloc plus Navicula had concentrations of 50,000 and 100,000 cells $\mathrm{mL}^{-1}$ achieved high concentrations of PUFA, mainly DHA and the shrimp presented a high amount of fatty acids when used Navicula since it had the high concentration of PUFA, mainly EPA and DHA (Khatoon et al., 2009).

The biochemical composition of microalgae varies according to the species and cultivation conditions used, such as temperature, $\mathrm{pH}$, salinity, luminosity, culture medium and culture system (George et al., 2014). Cultivation can be done in an autotrophic system, when using inorganic carbon and light as energy sources; heterotrophic by inserting organic carbon and source of organic energy in the absence of light; and mixotrophic, in the presence of organic and inorganic carbon, light and organic compounds as energy sources (Perez-García and Bashan, 2015). Some species are able to grow under all these conditions, and there may even be an increase in biomass and the production of organic molecules when grown in heterotrophic and mixotrophic systems (Perez-García and Bashan, 2015). Among the compounds produced by these microorganisms, lipids have a large participation, being polyunsaturated fatty acids that are important for shrimp larvae nutrition of (Martins et al., 2014). Thus, diatoms are preferred due to their high content of PUFAs (Ju et al., 2009).

Another way to offer microalgae and provide better utilization of their nutritional content is through bioencapsulation in a zooplankton organism, such as rotifers. Rotifers are important food for larvae of fish and crustacean in aquaculture. Their biochemical composition is influenced by the microalgae used in their production and can be manipulated according to the larvae nutritional requirements (Hoff and Snell, 2001). Brito et al. (2015) reported good results by adding Navicula sp. (50,000 cells $\left.\mathrm{mL}^{-1}\right)$ and the Brachionus plicatilis rotifer $\left(30 \mathrm{ind} \mathrm{mL}^{-1}\right)$ in a biofloc for L. vannamei where a final weight of $1.08 \mathrm{~g}$, yield of $2.46 \mathrm{~kg} \mathrm{~m}^{-3}$ and FCR of 0.92 were observed after 35 days of cultivation, while control treatment (without addition of organisms) resulted in a final weight of $0.68 \mathrm{~g}$, yield of $1.2 \mathrm{~kg}$ $\mathrm{m}^{-3}$, and FCR of 1.9 (Table 3).

These results confirmed that the combination of Navicula plus rotifer represents an excellent natural diet for the shrimp post-larvae, as they provide important nutritional compounds such as essential amino acids and highly unsaturated fatty acids that are important for the proper development of shrimp (Martins et al., 2014). The addition of these organisms also contributes to improving the biofloc composition and digestive enzyme activity, given the high protein content of shrimp and the highest protein efficiency ratio (2.73) (Brito et al., 2015). The biochemical composition of diatoms and rotifers may change under different cultural conditions.

According to Lavens and Sorgellos (1996), mixotrophic systems have a characteristic of being selfsustaining due to the formation of algae and also because they are less subject to deficiencies, such as food shortages. But water quality variables may be less subject to controls due to system dynamics. In these systems, added diatoms act by controlling the proliferation of cyanobacteria, and absorbing nitrogen and phosphate compounds from the environment, which can be detrimental to cultivation (Khatoon et al., 2009; Marinho et al., 2014, 2017). Also, there is the action of bacteria in the autotrophic nitrification process, where ammonia is transformed into nitrite and nitrite into nitrate (Ebeling et al., 2006), besides the absorption of ammonia by heterotrophic bacteria provided by the increased $\mathrm{C} / \mathrm{N}$ ratio, with the addition of carbohydrates (Crab et al., 2007). However, the rapid increase in total suspended solids (TSS) and volatile suspended solids (VSS) caused by high growth of microbial biomass may impair nutrient uptake by microalgae as a result of reduced light conditions, affecting water quality and shrimp production, particularly when the nitrification process is not well established (Ray et al., 2010; Gaona et al., 2017). In addition, high energy inputs and critical power 
failures (maximum one hour at any time) are intrinsic to this system (Taw and Chandaeng, 2005).

Thus, the main advantages of mixrotrophic systems are: minimal or zero water exchange, high biosecurity (from water), production 5-10\% better than photoautotrophic (algae based systems), shrimp size bigger by about $2.0 \mathrm{~g}$ than photoautotrophic systems, FCR low (1.0 - 1.3), production cost lower by around $15-20 \%$. In grown phase of $L$. vannamei farming, when using densities of 130 and 550 shrimp $\mathrm{m}^{-2}$, the production can reach 22,514 and $51,893 \mathrm{~kg}$ ha $^{-1}$, with shrimp weight of 18.78 and $13.8 \mathrm{~g}$, respectively (Taw and Chandaeng, 2005; Taw et al., 2011).

\section{Multi-trophic system}

Integrated multi-trophic aquaculture (IMTA) is based on the use of two or more species belonging to different trophic levels where metabolic wastes by one species are used by other organisms as a source of energy (Troell et al., 2009). Success of the IMTA system depends on the choice of species that will be integrated into the culture and other factors. It is necessary to assess the function that each organism plays in the system and to take into account the economic and commercial potential of each stocked species (Troell et al., 2009; Barrington et al., 2010). The use of IMTA enables a reduction of solid waste and better utilization of dissolved nutrients (Granada et al., 2016), resulting in an improvement in the water quality in the culture system. Although initially the concept of IMTA was developed to minimize environmental damage in offshore cultivation (Troell et al., 2009), it is possible to use its guidelines to improve water quality in systems that promote degradation of water quality throughout cultivation, as occurs in systems with minimal water exchange.

Characteristic water management of the BFT system such as minimal water exchange and the reuse of different proportions of liquid effluent from previous culture provides the accumulation of dissolved nutrients in the water (Burford et al. 2003; Krummenauer et al., 2014). These compounds are derived from the dissociation of uneaten food and by-products of animal metabolic reactions (Viadero et al., 2005). Silva et al. (2013) documented that over $60 \%$ of nitrogen and phosphate compounds used for feeding are not assimilated by the shrimp, and these are in the form of ammonia, nitrite, nitrate, and phosphate. Maximum values for concentrations of phosphate compounds are not known in marine shrimp under super-intensive systems, unlike nitrogen compounds, which negatively influence the growth and survival of L.vannamei due to their toxicity to these animals (Ebeling et al., 2006; Samocha et al., 2017). Moreover, the use of a high C:N ratio favors the development of heterotrophic bacteria. This community has higher nutrient conversion rates in bacterial biomass than nitrifying bacteria, thus contributing to the formation of particles called bioflocs (Ebeling et al., 2006), where rich concentrations of these suspended solids present in water can affect the development of marine shrimp (Schveitzer et al., 2013).
Given this problem, some studies have been conducted to evaluate the bioremediation potential, through integrating several organisms that are able to assimilate compounds dissolved in water such as mollusks (Petersen et al., 2017), fish (Shpigel et al., 2016), microalgae (Magnotti et al., 2016) and marine macroalgae (Brito et al., 2013, 2014a, 2014b; Samocha et al., 2015), integrating them into the culture of marine shrimp, offering good productive results (Table 4).

Among these organisms, macroalgae have a high potential for use in integrated systems in aquaculture due to their bioremediation action. In addition, according to Attasat et al. (2013), an increase in shrimp biomass of $15 \%$ is possible by using an integrated system between these and macroalgae. Besides enabling this increase, it has high efficiency in removing nitrate and phosphate compounds from the environment in which they are inserted. Decreases in ammonia concentrations from 35 to $100 \%$ (Castelar et al., 2015; Rahardjo et al., 2018), nitrite 26 to $84 \%$ (Rahardjo et al., 2018; Brito et al., 2018a), nitrate 17 to $99 \%$ (Castelar et al., 2015; Rahardjo et al., 2018), in addition to the removal of 25 to $63.1 \%$ of phosphate compounds have been reported (Macchiavello and Bulboa, 2014; Brito et al., 2018a) (Table 5). In addition, the improvement in water quality resulting from the use of the macroalgae can be seen through the influence on the microbiological and phytoplanktonic community of the culture systems, due to the growth of beneficial microalgae for the shrimp culture in the system where the macroalgae are used (Elle et al., 2017).

Macroalgae, besides contributing to their bioremediation potential, may also favor the zootechnical performance of the animals, as they can be used as a food source in the culture of aquatic animals (Fleurence et al., 2012), and may contribute in the form of substrate for biofilm formation when stored in the culture units or acting as a supplementary food source. This is because of their rich amounts of protein, lipids, and essential amino acids among other nutrients. (Tabarsa et al., 2012). The macroalgae of the genus Gracilaria sp. may have 6.4 to $37.6 \%$ of protein and 0.2 to $12.9 \%$ of lipid (Haslun et al., 2012; Øverland et al., 2019), serving not only as a source of high nutritional value but also as a functional ingredient due to their probiotic or antioxidant properties (Niu et al., 2019).

In assessing the effect of the presence of several organisms, the benefits are related not only to water quality parameters but also their contribution to the marine shrimp zootechnical performance indexes (Table 6). Furthermore, it is even possible to reduce the amount of feed protein in the nursery phase by virtue of the presence of these organisms in the system. Thus, integrating two or more organisms with super-intensive culture is a promising strategy for reducing nutrient concentrations in the farming effluents, and contributing through food supplementation directly (used as a food source) or indirectly (used as adhesion substrate) for the growth and condition of the stocked species of the shrimp. 
Table 4. Zootechnical performance of marine shrimp reared in multi-trophic systems.

\begin{tabular}{|c|c|c|c|c|c|c|c|c|}
\hline IMTA System & Shrimp specie & Phase & $\begin{array}{c}\text { Stocking } \\
\text { density } \\
\text { (shrimp) }\end{array}$ & Yield & $\begin{array}{c}\text { Final } \\
\text { weight } \\
\text { (g) }\end{array}$ & $\begin{array}{c}\text { Survival } \\
(\%)\end{array}$ & $\begin{array}{l}\text { Time } \\
\text { (days) }\end{array}$ & Reference \\
\hline $\begin{array}{l}\text { Sargassum } \\
\text { plagyophyllum }\end{array}$ & P. monodon & $\mathrm{N}$ & $50 \mathrm{~m}^{-3}$ & $563 \mathrm{~kg} \mathrm{ha}^{-1}$ & 1.33 & 85 & 30 & \multirow{2}{*}{ Izzati (2011) } \\
\hline $\begin{array}{l}\text { Gracillaria } \\
\text { verrucosa }\end{array}$ & P. monodon & $\mathrm{N}$ & $50 \mathrm{~m}^{-3}$ & $740 \mathrm{~kg} \mathrm{ha}^{-1}$ & 1.66 & 89 & 30 & \\
\hline $\begin{array}{l}\text { Caulerpa } \\
\text { sertularioides }\end{array}$ & F. californiensis & $\mathrm{N}$ & $28 \mathrm{~m}^{-2}$ & $0.18 \mathrm{~kg} \mathrm{~m}^{-2}$ & - & 98 & 60 & $\begin{array}{l}\text { Portillo-Clark et al. } \\
\text { (2012) }\end{array}$ \\
\hline G. birdiae & L. vannamei & $\mathrm{N}$ & $500 \mathrm{~m}^{-3}$ & $1.96 \mathrm{~kg} \mathrm{~m}^{-3}$ & 4.12 & 95 & 42 & Brito et al. (2014b) \\
\hline G. birdiae & L. vannamei & $\mathrm{N}$ & $500 \mathrm{~m}^{-3}$ & $1.71 \mathrm{~kg} \mathrm{~m}^{-3}$ & 3.87 & 93 & 42 & Brito et al. (2018b) \\
\hline Ulva lactuca & L. vannamei & $\mathrm{N}$ & $10 \mathrm{~m}^{-3}$ & $0.02 \mathrm{~kg} \mathrm{~m}^{-3}$ & 2.08 & 96 & 28 & $\begin{array}{c}\text { Elizondo-Gonzalés } \\
\text { et al. (2018) }\end{array}$ \\
\hline G. dichotoma & L. vannamei & $\mathrm{N}$ & $300 \mathrm{~m}^{-3}$ & $1.12 \mathrm{~kg} \mathrm{~m}^{-3}$ & 3.9 & 96 & 30 & \multirow{2}{*}{$\begin{array}{c}\text { Anaya-Rosas et al. } \\
\text { (2019) }\end{array}$} \\
\hline G. vermiculophylla & L. vannamei & $\mathrm{N}$ & $300 \mathrm{~m}^{-3}$ & $1.13 \mathrm{~kg} \mathrm{~m}^{-3}$ & 4.0 & 94 & 30 & \\
\hline G. tenuistipitata & L. vannamei & $\mathrm{N}$ & $3000 \mathrm{~m}^{-3}$ & 2719 ind $\mathrm{m}^{-3}$ & 0.31 & 91 & 30 & Anh et al. (2019) \\
\hline Crassostrea gigas & L. vannamei & $\mathrm{N}$ & $200 \mathrm{~m}^{-2}$ & $0.51 \mathrm{~kg} \mathrm{~m}^{-2}$ & 2.73 & 94 & 30 & Omont et al. (2020) \\
\hline Mugil liza & L. vannamei & $\mathrm{N}$ & $2500 \mathrm{~m}^{-3}$ & $3.34 \mathrm{~kg} \mathrm{~m}^{-1}$ & 1.37 & 98 & 41 & Borges et al. (2020) \\
\hline U. lactuca & L. vannamei & G & $132 \mathrm{~m}^{-2}$ & $3.72 \mathrm{~kg} \mathrm{~m}^{-2}$ & 7.04 & 93 & 28 & Brito et al. (2013) \\
\hline G. birdiae & L. vannamei & G & $425 \mathrm{~m}^{-3}$ & $1.4 \mathrm{~kg} \mathrm{~m}^{-3}$ & 6.57 & 50 & 28 & \multirow{2}{*}{ Brito et al. (2014a) } \\
\hline G. domingensis & L. vannamei & G & $425 \mathrm{~m}^{-3}$ & $1.37 \mathrm{~kg} \mathrm{~m}^{-3}$ & 5.75 & 56 & 28 & \\
\hline G. tikvahiae & L. vannamei & $\mathrm{G}$ & $92 \mathrm{~m}^{-2}$ & $3.2 \mathrm{~kg} \mathrm{~m}^{-2}$ & 26.7 & 100 & 67 & $\begin{array}{l}\text { Samocha et al. } \\
\text { (2015) }\end{array}$ \\
\hline G. corticata & L. vannamei & G & $50 \mathrm{~m}^{-2}$ & $0.47 \mathrm{~kg} \mathrm{~m}^{-2}$ & 13.4 & 71 & 45 & $\begin{array}{l}\text { Fourooghifard et al. } \\
\text { (2017) }\end{array}$ \\
\hline U. clathrata & F. californiensis & $\mathrm{G}$ & $30 \mathrm{~m}^{-2}$ & $0.28 \mathrm{~kg} \mathrm{~m}^{-2}$ & 12.0 & 79 & 126 & $\begin{array}{l}\text { Peña-Rodríguez et } \\
\text { al. (2017) }\end{array}$ \\
\hline U. prolifera & L. vannamei & G & $500 \mathrm{~m}^{-3}$ & $4.78 \mathrm{~kg} \mathrm{~m}^{-3}$ & 10.2 & 93.8 & 35 & Ge et al. (2018) \\
\hline Mugil cephalus & L. vannamei & G & $60 \mathrm{~m}^{-3}$ & $0.40 \mathrm{~kg} \mathrm{~m}^{-3}$ & 10.7 & 63 & 75 & Hoang et al. (2018) \\
\hline $\begin{array}{l}\text { C.cuttackensis + } \\
\text { Entreromorpha }\end{array}$ & P. monodon & $\mathrm{G}$ & 30000 ha $^{-1}$ & $781 \mathrm{~kg} \mathrm{ha}^{-1}$ & 35.9 & - & 150 & Biswas et al. (2019) \\
\hline $\begin{array}{l}\text { Oreochromis } \\
\text { niloticus }\end{array}$ & L. vannamei & G & $10 \mathrm{~m}^{-2}$ & $0.12 \mathrm{~kg} \mathrm{~m}^{-2}$ & 15.1 & 78 & 106 & $\begin{array}{c}\text { Juárez-Rosales et } \\
\text { al. (2019) }\end{array}$ \\
\hline $\begin{array}{l}\text { O. niloticus + } \\
\text { S. ambigua } \\
\end{array}$ & L. vannamei & $\mathrm{G}$ & $312 \mathrm{~m}^{-3}$ & $3.9 \mathrm{~kg} \mathrm{~m}^{-3}$ & 14.6 & 88 & 57 & Poli et al. (2019) \\
\hline
\end{tabular}

N: Nursery phase; G: Grow-out phase. 
Table 5. Nutrient uptake by macroalgae in IMTA systems.

\begin{tabular}{|c|c|c|c|c|c|}
\hline Species & $\begin{array}{c}\text { Ammonia } \\
(\%)\end{array}$ & $\begin{array}{c}\text { Nitrite } \\
\text { (\%) }\end{array}$ & $\begin{array}{c}\text { Nitrate } \\
(\%)\end{array}$ & $\begin{array}{c}\text { Phosphate } \\
\text { (\%) }\end{array}$ & Reference \\
\hline Ulva lactuca & 94 & - & - & 40 & Alencar et al. (2010) \\
\hline Ulva fasciata & 50 & 31 & 70 & - & Ramos et al. (2010) \\
\hline Gracilaria manilaensis & 83 & 33 & 68 & - & Shukri and Surif (2011) \\
\hline Gracilaria vermiculophyla & 90 & - & - & 82 & \multirow{2}{*}{ Skriptsova and Miroshnikova (2011) } \\
\hline Undaria pinnatifida & 72 & - & - & 74 & \\
\hline Gracilaria caudata & 23 & 57 & 70 & - & Marinho-Soriano et al. (2011) \\
\hline Gracilaria vermiculophylla & 100 & - & 58 & - & Abreu et al. (2011) \\
\hline Gracilaria verrucosa & 54 & 50 & 76 & 49 & Huo et al. (2011) \\
\hline Gracilaria verrucosa & 61 & 48 & 47 & 58 & Huo et al. (2012) \\
\hline Ulva lactuca & 83 & - & - & 41 & \multirow[b]{2}{*}{ Al-Hafedh et al. (2012) } \\
\hline Gracilaria arcuata & 80 & - & - & 41 & \\
\hline Hydropuntia cornea & 88 & 23 & - & - & Robledo et al. (2012) \\
\hline Ulva lactuca & 88.2 & - & - & - & Ben-Ari et al. (2014) \\
\hline Gracilariopsis longissima & 97 & 87 & 87 & 77 & He et al. (2014) \\
\hline Gracilaria edulis & 70 & - & - & - & \multirow[b]{2}{*}{ Lavania-Baloo et al. (2014) } \\
\hline Ulva lactuca & 45 & - & - & - & \\
\hline Ulva lactuca & 100 & - & 83 & 65 & \multirow[b]{2}{*}{ Macchiavello and Bulboa (2014) } \\
\hline Gracilaria chilensis & 100 & - & 88 & 38 & \\
\hline G. birdiae + Ulva spp. & 98 & 87 & 98 & 62 & Castelar et al. (2015) \\
\hline Macrocystis pyrifera & 75 & - & - & - & Hadley et al. (2015) \\
\hline Gracilaria sp. & 36 & $11-27$ & 18 & - & \multirow{3}{*}{ Rahardjo et al. (2018) } \\
\hline Caulerpa sp. & 25 & $4-21$ & 12 & - & \\
\hline Eucheuma sp. & 12 & $1-25$ & 9 & - & \\
\hline
\end{tabular}


Table 6. Zootechnical performance of marine shrimp reared in IMTA systems and monoculture.

\begin{tabular}{|c|c|c|c|c|c|c|c|}
\hline Shrimp specie & Phase & $\begin{array}{l}\text { Monoculture / } \\
\text { IMTA system }\end{array}$ & $\begin{array}{c}\text { Final } \\
\text { weight } \\
\text { (g) }\end{array}$ & $\begin{array}{l}\text { SGR (\% } \\
\left.d^{-1}\right)\end{array}$ & Yield & $\begin{array}{l}\text { Survival } \\
(\%)\end{array}$ & Reference \\
\hline \multirow{3}{*}{ P. monodon } & \multirow{3}{*}{$\mathrm{N}$} & Monoculture & 1.25 & - & $445 \mathrm{~kg} \mathrm{ha}^{-1}$ & 71 & \multirow{3}{*}{ Izzati (2011) } \\
\hline & & S. plagyophyllum & 1.33 & - & $563 \mathrm{~kg} \mathrm{ha}^{-1}$ & 85 & \\
\hline & & G. verrucosa & 1.66 & - & $740 \mathrm{~kg} \mathrm{ha}^{-1}$ & 89 & \\
\hline \multirow{2}{*}{ F. californiensis } & \multirow{2}{*}{$\mathrm{N}$} & Monoculture & - & - & $0.09 \mathrm{~kg} \mathrm{~m}^{-2}$ & 84 & \multirow{2}{*}{$\begin{array}{l}\text { Portillo-Clark et al. } \\
\qquad \text { (2012) }\end{array}$} \\
\hline & & C. sertularioides & - & - & $0.18 \mathrm{~kg} \mathrm{~m}^{-2}$ & 98 & \\
\hline \multirow{2}{*}{ L. vannamei } & \multirow{2}{*}{$\mathrm{N}$} & Monoculture & 3.12 & 5.42 & $1.41 \mathrm{~kg} \mathrm{~m}^{-3}$ & 90 & \multirow{2}{*}{ Brito et al. (2014b) } \\
\hline & & G. birdiae & 4.12 & 5.86 & $1.96 \mathrm{~kg} \mathrm{~m}^{-3}$ & 95 & \\
\hline \multirow{2}{*}{ L. vannamei } & \multirow{2}{*}{$\mathrm{N}$} & Monoculture & 3.21 & - & $1.39 \mathrm{~kg} \mathrm{~m}^{-3}$ & 83 & \multirow{2}{*}{ Brito et al. (2018b) } \\
\hline & & G. birdiae & 3.87 & - & $1.71 \mathrm{~kg} \mathrm{~m}^{-3}$ & 93 & \\
\hline \multirow{2}{*}{ L. vannamei } & \multirow{2}{*}{$\mathrm{N}$} & Monoculture & 1.82 & 6.42 & $0.02 \mathrm{~kg} \mathrm{~m}^{-3}$ & 83 & \multirow{2}{*}{$\begin{array}{c}\text { Elizondo-Gonzalés et } \\
\text { al. (2018) }\end{array}$} \\
\hline & & U. lactuca & 2.08 & 6.91 & $0.07 \mathrm{~kg} \mathrm{~m}^{-3}$ & 96 & \\
\hline \multirow{3}{*}{ L. vannamei } & \multirow{3}{*}{$\mathrm{N}$} & Monoculture & 3.9 & - & $1.17 \mathrm{~kg} \mathrm{~m}^{-3}$ & 100 & \multirow{3}{*}{$\begin{array}{l}\text { Anaya-Rosas et al. } \\
\text { (2019) }\end{array}$} \\
\hline & & G. vermiculophylla & 4.0 & - & $1.13 \mathrm{~kg} \mathrm{~m}^{-3}$ & 94 & \\
\hline & & D. dichotoma & 3.9 & - & $1.12 \mathrm{~kg} \mathrm{~m}^{-3}$ & 96 & \\
\hline \multirow{2}{*}{ L. vannamei } & \multirow{2}{*}{$\mathrm{N}$} & Monoculture & 0.31 & 3.86 & 2178 ind $\mathrm{m}^{-3}$ & 72.6 & \multirow{2}{*}{ Anh et al. (2019) } \\
\hline & & G. tenuistipitata & 0.31 & 3.89 & 2719 ind $\mathrm{m}^{-3}$ & 90.6 & \\
\hline \multirow{2}{*}{ L. vannamei } & \multirow{2}{*}{$\mathrm{N}$} & Monoculture & 1.5 & 5.17 & $3.75 \mathrm{~kg} \mathrm{~m}^{-1}$ & 98.7 & \multirow{2}{*}{ Borges et al. (2020) } \\
\hline & & Mugil liza & 1.37 & 4.96 & $3.34 \mathrm{~kg} \mathrm{~m}^{-1}$ & 97.2 & \\
\hline \multirow{2}{*}{ L. vannamei } & \multirow{2}{*}{$\mathrm{N}$} & Monoculture & 2.47 & 6.2 & $0.46 \mathrm{~kg} \mathrm{~m}^{-2}$ & 94 & Omont at al (2020) \\
\hline & & C.gigas & 2.73 & 6.48 & $0.51 \mathrm{~kg} \mathrm{~m}^{-2}$ & 94 & Umont etal. $(\angle 0 \angle 0)$ \\
\hline & & Monoculture & 6.55 & 0.98 & $3.56 \mathrm{~kg} \mathrm{~m}^{-3}$ & 96 & \\
\hline L. vannamel & G & U. lactuca & 7.04 & 1.38 & $3.72 \mathrm{~kg} \mathrm{~m}^{-3}$ & 93 & Brito et al. (2013) \\
\hline & & Monoculture & 5.42 & 1.56 & $1.3 \mathrm{~kg} \mathrm{~m}^{-3}$ & 56 & \\
\hline L. vannamei & $\mathrm{G}$ & G. birdiae & 6.57 & 2.12 & $1.4 \mathrm{~kg} \mathrm{~m}^{-3}$ & 50 & Brito et al. (2014a) \\
\hline & & G. domingensis & 5.75 & 1.81 & $1.37 \mathrm{~kg} \mathrm{~m}^{-3}$ & 56 & \\
\hline & $C$ & Monoculture & 12.5 & 1.7 & $0.32 \mathrm{~kg} \mathrm{~m}^{-2}$ & 51 & Fourooghifard et al. \\
\hline L. vannamel & G & G. corticata & 13.4 & 1.85 & $0.47 \mathrm{~kg} \mathrm{~m}^{-2}$ & 71 & $(2017)$ \\
\hline yannamei & $\mathrm{G}$ & Monoculture & 10.1 & - & $0.38 \mathrm{~kg} \mathrm{~m}^{-3}$ & 62 & Hoano et al (2018) \\
\hline L. vannamel & G & Mugil cephalus & 10.7 & - & $0.40 \mathrm{~kg} \mathrm{~m}^{-3}$ & 63 & Hoang el al. (2018) \\
\hline L vannamei & $G$ & Monoculture & 5.1 & 3.0 & $0.71 \mathrm{~kg} \mathrm{~m}^{-2}$ & 81 & Laramore et al. \\
\hline L. vannamel & G & U. lactuca & 5.2 & 3.2 & $0.69 \mathrm{~kg} \mathrm{~m}^{-2}$ & 83 & (2018) \\
\hline & & Monoculture & 32.4 & - & $662 \mathrm{~kg} \mathrm{ha}^{-1}$ & - & \\
\hline P. monodon & G & $\begin{array}{c}\text { C. cuttackensis }+ \\
\text { Entreromorpha spp. }\end{array}$ & 35.9 & - & $781 \mathrm{~kg} \mathrm{ha}^{-1}$ & - & Biswas et al. (2019) \\
\hline Lannamei & $G$ & Monoculture & 14.8 & 3.0 & $0.10 \mathrm{~kg} \mathrm{~m}^{-2}$ & 69 & Juárez-Rosales et al. \\
\hline L. Vutritumtet & a & O. niloticus & 15.1 & 3.0 & $0.12 \mathrm{~kg} \mathrm{~m}^{-2}$ & 78 & $(2019)$ \\
\hline & & Monoculture & 14.1 & - & $3.9 \mathrm{~kg} \mathrm{~m}^{-3}$ & 89.3 & \\
\hline L. vannamei & G & $\begin{array}{l}\text { O. niloticus }+S \text {. } \\
\text { ambigua }\end{array}$ & 14.6 & - & $3.9 \mathrm{~kg} \mathrm{~m}^{-3}$ & 88 & Poli et al. (2019) \\
\hline
\end{tabular}

N: Nursery phase; G: Grow-out phase; SGR: Specific Growth Rate. 


\section{Conclusions}

Photoheterotrophic, mixotrophic and multi-trophic culture systems are interesting alternatives to conventional (photoautotrophic) systems for marine shrimp production. The good zootechnical performance and environmental benefits provide models that promote the minimum exchange of water and the best utilization of the nutrients available in the environment, thereby reducing the effluent generation. It should be mentioned that the algal biomass obtained can be used in food preparation technologies for aquafeed. On the other hand, it will be possible to explore the presence of biomolecules produced by the dominant algae that could be of application in nutraceutical and pharmaceutical industries. Of course, this will require investment in research and development for purposeful outcomes.

\section{References}

Abdelnour, S.A., Abd El-Hack, M.E., Arif, M. \& Khafaga, A.F. (2019). The application of the microalgae Chlorella spp. as a supplement in broiler feed. World's Poultry Science Journal 75, 1-14. DOI: 10.1017/S0043933919000047

Abreu, M.H., Pereira, R., Buschmann, A.H., Sousa-Pinto, I. \& Yarish, C. (2011). Nitrogen uptake responses of Gracilaria vermiculophylla (Ohmi) Papenfuss under combined and single addition of nitrate and ammonium. Journal of Experimental Marine Biology and Ecology 407(2), 190-199. DOI:10.1016/j.jembe.2011.06.034

Abreu, J.L., Brito, L.O., Lima, P.C.M., Silva, S.M.B.C, Severi, W. \& Gálvez, A.O. (2019). Effects of addition of Navicula sp.(diatom) in different densities to postlarvae of shrimp Litopenaeus vannamei reared in a BFT system: Growth, survival, productivity and fatty acid profile. Aquaculture Research 50(8), 2231-2239. DOI:10.1111/are.14104

Alencar, J.R., Junior, P.A.H. \& Celino, J.J. (2010). Cultivo de Camarão Branco Litopenaeus vannamei (Boone, 1931) com a Macro-alga Ulva lacuata Linneaus (Chlorophyta) no Tratamento de Efluentes em Sistema Fechado de Recirculação. Revista de Biologia e Ciências da Terra 10(1), 117-137.

Al-Hafedh, Y.S., Alam, A., Buschmann, A.H. \& Fitzsimmons, K.M. (2012). Experiments on an integrated aquaculture system (seaweeds and marine fish) on the Red Sea coast of Saudi Arabia: efficiency comparison of two local seaweed species for nutrient biofiltration and production. Reviews in Aquaculture 4(1), 21-31. DOI:10.1111/j.1753-5131.2012.01057.x

Anand, P.S., Kohli, M.P.S., Kumar, S., Sundaray, J.K., Roy, S.D., Venkateshwarlu, G., ... \& Pailan, G.H. (2014). Effect of dietary supplementation of biofloc on growth performance and digestive enzyme activities in Penaeus monodon. Aquaculture 418, 108-115. DOI:10.1016/j.aquaculture.2013.09.051

Anaya-Rosas, R.E., Rivas-Vega, M.E., Miranda-Baeza, A., Piña-Valdez, P. \& Nieves-Soto, M. (2019). Effects of a co-culture of marine algae and shrimp (Litopenaeus vannamei) on the growth, survival and immune response of shrimp infected with Vibrio parahaemolyticus and white spot virus (WSSV). Fish \& Shellfish Immunology 87, 136-143. DOI:10.1016/j.fsi.2018.12.071

Anh, N.T.N., An, B.N.T., Lan, L.M. \& Hai, T. N. (2019). Integrating different densities of white leg shrimp Litopenaeus vannamei and red seaweed Gracilaria tenuistipitata in the nursery phase: effects on water quality and shrimp performance. Journal of Applied Phycology 31(5), 3223-3234. DOI:10.1007/s10811-019-01824-7

Arnold, S.J., Coman, F. E., Jackson, C.J. \& Groves, S.A. (2009). Highintensity, zero water-exchange production of juenile tiger shrimp, Penaeus monodon: an evaluation of artificial substrates and stocking density. Aquaculture 293(1-2), DOI:10.1016/j.aquaculture.2009.03.049
Attasat, S., Wanichpongpan, P. \& Ruenglertpanyakul, W. (2013). Design of integrated aquaculture of the Pacific white shrimp, tilapia and green seaweed. Journal of Sustainable Energy and Environment, 4, 9-14.

Avnimelech,Y. (2007). Feeding with microbial flocs by tilapia in minimal discharge bio-flocs technology ponds. Aquaculture 264, 140-147. DOI:10.1016/j.aquaculture.2006.11.025

Avnimelech, Y. (2009). Biofloc technology - a practical guide book. The World Aquaculture Society, 182 pp. Baton Rouge, Louisiana, USA.

Ballester, E.L.C., Wasielesky Jr, W., Cavalli, R.O. \& Abreu, P.C. (2007). Nursery of the pink shrimp Farfantepenaeus paulensis in cages with artificial substrates: biofilm composition and shrimp performance. Aquaculture 269(1-4), 355-362. DOI:10.1016/j.aquaculture. 2007.04.003

Ballester, E.L.C., Abreu, P.C., Cavalli, R.O., Emerenciano, M., De Abreu, L. \& Wasielesky Jr, W. (2010). Effect of practical diets with different protein levels on the performance of Farfantepenaeus paulensis juveniles nursed in a zero exchange suspended microbial flocs intensive system. Aquaculture Nutrition 16(2), 163-172. DOI:10.1111/j.1365-2095.2009.00648.x

Barrington, K., Ridler, N., Chopin, T., Robinson, S. \& Robinson, B. (2010). Social aspects of the sustainability of integrated multi-trophic aquaculture. Aquaculture International 18(2), 201-211. DOI:10.1007/s10499-0089236-0

Becerra-Dorame, M.J., Martínez-Porchas, M., Martínez-Córdova, L.R., Rivas-Vega, M.E., Lopez-Elias, J.A. \& Porchas-Cornejo, M.A. (2012). Production response and digestive enzymatic activity of the Pacific white shrimp Litopenaeus vannamei (Boone, 1931) intensively pregrown in microbial heterotrophic and autotrophic-based systems. The Scientific World Journal. DOI:10.1100/2012/723654

Ben-Ari, T., Neori, A., Ben-Ezra, D., Shauli, L., Odintsov, V. \& Shpigel, M. (2014). Management of Ulva lactuca as a biofilter of mariculture effluents in IMTA system. Aquaculture 434, 493-498. DOI:10.1016/j.aquaculture. 2014.08.034

Biró, P. (1995). Management of pond ecosystems and trophic webs. Aquaculture 129, 373-386. DOI: 10.1016/0044-8486(94)00291-U

Biswas, G., Kumar, P., Kailasam, M., Ghoshal, T.K., Bera, A. \& Vijayan, K.K. (2019). Application of Integrated Multi Trophic Aquaculture (IMTA) Concept in Brackishwater Ecosystem: The First Exploratory Trial in the Sundarban, India. Journal of Coastal Research 86(SI), 49-55. DOI:10.2112/SI86-007.1

Borges, B.A., Rocha, J.L., Pinto, P.H.O., Zacheu, T., Chede, A.C., Magnotti, C.C.F. \& Arana, L.A.V. (2020). Integrated culture of white shrimp Litopenaeus vannamei and mullet Mugil liza on biofloc technology: Zootechnical performance, sludge generation, and Vibrio spp. reduction. Aquaculture 735234. DOI:10.1016/j.aquaculture.2020.735234

Boyd, C.E. (1997). Practical Aspects of Chemistry in Pond Aquaculture. The Progressive Fish-Culturist 59, 85-93. DOI: $10.1577 / 1548-$ 8640(1997)059<0085:PAOCIP>2.3.C0;2

Boyd, C.E. \& Tucker, C.S. (1998). Pond Aquaculture Water Quality Management. New York: Springer Science \& Business Media, 700 pp. DOI: 10.1007/978-1-4615-5407-3

Boyd, C. E. \& Queiroz, J. F. (2001). Nitrogen, phosphorus loads vary by system. The Advocate, 84-86.

Boyd, C.E. (2015). Water quality: An Introduction. New London: Springer, 2nd edition, 427 pp. DOI 10.1007/978-3-319-17446-4

Brito, L.O., de Melo Costa, W. \& Gálvez, A.O. (2006). Utilização de nitrato de sódio como estratégia de fertilização na produção do camarão Litopenaeus vannamei. Boletim do Instituto de Pesca 32(1), 95-100.

Brito, L.O., Arantes, R., Magnotti, C., Derner, R., Pchara, F., Olivera, A. \& Vinatea, L. (2013). Water quality and growth of Pacific white shrimp Litopenaeus vannamei (Boone) in co-culture with green seaweed Ulva lactuca (Linaeus) in intensive system. Aquaculture International 22(2), 497-508. DOI:10.1007/s10499-013-9659-0 
Brito, L.O., Arana, L.A.V., Soares, R.B., Severi, W., Miranda, R.H., da Silva, S.M.B. C. \& Gálvez, A.O. (2014a). Water quality, phytoplankton composition and growth of Litopenaeus vannamei (Boone) in an integrated biofloc system with Gracilaria birdiae (Greville) and Gracilaria domingensis (Kützing). Aquaculture International 22(5), 1649-1664. DOI:10.1007/s10499-014-9771-9

Brito, L.O., Chagas, A.M., da Silva, E.P., Soares, R.B., Severi, W. \& Gálvez, A. O. (2014b). Water quality, Vibrio density and growth of Pacific white shrimp Litopenaeus vannamei (Boone) in an integrated biofloc system with red seaweed Gracilaria birdiae (Greville). Aquaculture Research 47(3), 940950. DOI:10.1111/are.12552.

Brito, L.O., dos Santos, I.G.S., de Abreu, J.L., de Araújo, M.T., Severi, W. \& Gàlvez, A.O. (2015). Effect of the addition of diatoms (Navicula spp.) and rotifers (Brachionus plicatilis) on water quality and growth of the Litopenaeus vannamei postlarvae reared in a biofloc system. Aquaculture Research 47(12), 3990-3997. DOI: 10.1111/are.12849

Brito, L.O., Cardoso Junior, L.D.O., Lavander, H.D., Abreu, J.L.D., Severi, W. \& Gálvez, A.O. (2018a). Bioremediation of shrimp biofloc wastewater using clam, seaweed and fish. Chemistry and Ecology 34(10), 901-913. DOI: 10.1080/02757540.2018.1520843.

Brito, L.O., Junior, L.C., Abreu, J.L., Severi, W., Moraes, L.B. \& Gálvez, A.O. (2018b). Effects of two commercial feeds with high and low crude protein content on the performance of white shrimp Litopenaeus vannamei raised in an integrated biofloc system with the seaweed Gracilaria birdiae. Spanish Journal of Agricultural Research 16(1), 13. DOI:10.5424/sjar/201816111451

Burford, M.A., Thompson, P.J., McIntosh, R.P., Bauman, R.H. \& Pearson, D.C. (2003). Nutrient and microbial dynamics in high-intensity, zeroexchange shrimp ponds in Belize. Aquaculture 219 (1-4), 393-411. DOI:10.1016/s0044-8486(02)00575-6

Casillas-Hernández, R., Nolasco-Soria, H., García-Galano, T., CarrilloFarnes, 0. \& Páez-Osuna, F. (2007). Water quality, chemical fluxes and production in semi-intensive Pacific white shrimp (Litopenaeus vannamei) culture ponds utilizing two different feeding strategies. Aquacultural Engineering 36(2), 105-114. DOI:10.1016/j.aquaeng.2006.09.001

Castelar, B., Pontes, M.D., de Melo Costa, W., Moura, L.C., Dias, G.E., Landuci, F.S. \& Reis, R.P. (2015). Biofiltering efficiency and productive performance of macroalgae with potential for integrated multi-trophic aquaculture (IMTA). Boletim do Instituto de Pesca 41, 763-770.

Chamberlain, G., Avnimelech, Y., McIntoch, R.P. \& Velasco, M. (2001). Advantages of aerated microbial reuse systems with balanced C:N. II: Composition and nutritional value of organic detritus. Global Aquaculture Advocate 4(4), 22-24.

Cordova, L.R.M., Torres, A.C. \& Cornejo, M.A.P. (2002). Promotion and contribution of biota in low water exchange ponds farming blue shrimp Litopenaeus stylirostris (Stimpson). Aquaculture Research 33(1), 27-32. DOI:10.1046/j.1355-557X.2001.00639.x

Crab, R., Avnimelech, Y., Defoirdt, T., Bossier, P. \& Verstraete, W. (2007). Nitrogen removal techniques in aquaculture for a sustainable production. Aquaculture 270, 1-14. DOI: 10.1016/j.aquaculture.2007.05.006

De Schryver, P., Crab, R., Defoirdt, T., Boon, N. \& Verstraete, W. (2008). The basics of bio-flocs technology: the added value for aquaculture. Aquaculture 277, 125-137. DOI: 10.1016/j.aquaculture.2008.02.019

Diana, J.S., Szyper, J.P., Batterson, T.R., Boyd, C.E. \& Piedrahita, R.H. (1997). Water Quality in Ponds. In: Dynamics of Pond Aquaculture (H.S. Egna \& C.E. Boyd, eds.), pp 53-71. CRC Press, Boca Raton, FL.

Ebeling, J.M., Timmons, M.B. \& Bisogni, J.J. (2006). Engineering analysis of the stoichiometry of photoautotrophic, autotrophic, and heterotrophic removal of ammonia-nitrogen in aquaculture systems. Aquaculture 257(14), 346-358. DOI:10.1016/j.aquaculture.2006.03.019

Elizondo-González, R., Quiroz-Guzmán, E., Escobedo-Fregoso, C., Magallón-Servín, P. \& Peña-Rodríguez, A. (2018). Use of seaweed Ulva lactuca for water bioremediation and as feed additive for white shrimp Litopenaeus vannamei. PeerJ 6, e4459. DOI:10.7717/peerj.4459
Elle, B.J., Corre Jr, V., Felarca, K.G. \& Pedroso, F. (2017). Potential of Gracilariopsis bailiniae and Oreochromis mossambicus in improving water quality in intensive Litopenaeus vannamei tank culture. Aquaculture, Aquarium, Conservation \& Legislation 10(5), 1309-1318.

Emerenciano, M., Ballester, E.L., Cavalli, R.O. \& Wasielesky, W. (2011). Effect of biofloc technology (BFT) on the early postlarval stage of pink shrimp Farfantepenaeus paulensis: growth performance, floc composition and salinity stress tolerance. Aquaculture International 19(5), 891-901. DOI:10.1007/s10499-010-9408-6

Emerenciano, M., Ballester, E.L., Cavalli, R.O. \& Wasielesky, W. (2012). Biofloc technology application as a food source in a limited water exchange nursery system for pink shrimp Farfantepenaeus brasiliensis (Latreille, 1817). Aquaculture Research 43(3), 447-457. DOI:10.1111/j.13652109.2011.02848.x

Emerenciano, M., Cuzon, G., Paredes, A. \& Gaxiola, G. (2013a). Evaluation of biofloc technology in pink shrimp Farfantepenaeus duorarum culture: growth performance, water quality, microorganisms profile and proximate analysis of biofloc. Aquaculture International 21(6), 1381-1394. DOI:10.1007/s10499-013-9640-y

Emerenciano, M., Gaxiola, G. \& Cuzon, G. (2013b). Biofloc technology (BFT): a review for aquaculture application and animal food industry. In: Biomass now-cultivation and utilization (M. Matovic, ed.), pp 301-323. InTech, Rijeka, $\mathrm{Hr}$.

FAO. Food and Agricultural Organization. (2018). The state of world fisheries and aquaculture 2018. Rome: FAO.

Fleurence, J., Morançais, M., Dumay, J., Decottignies, P., Turpin, V., Munier, M. \& Jaouen, P. (2012). What are the prospects for using seaweed in human nutrition and for marine animals raised through aquaculture? Trends in Food Science \& Technology 27(1), 57-61. DOI: 10.1016/j.tifs.2012.03.004.

Fóes, G. K., Fróes, C., Krummenauer, D., Poersch, L. \& Wasielesky, W. (2011). Nursery of pink shrimp Farfantepenaeus paulensis in biofloc technology culture system: survival and growth at different stocking densities. Journal of Shellfish Research 30(2), 367-373. DOI:10.2983/035.030.0224

Fourooghifard, H., Matinfar, A., Mortazavi, M. S., Roohani Ghadikolaee, K. \& Mirbakhsh, M. (2017). Growth parameters of whiteleg shrimp Litopenaeus vannamei and red seaweed Gracilaria corticata in integrated culturing method under zero water exchange system. Aquaculture Research 48(10), 5235-5242. DOI:10.1111/are.13335

Freeman, D.W., Duerr, E.O. \& Leber, K.M. (1992). Use of bagasse as a feed input to semi-intensive shrimp growout ponds. Journal of the World Aquaculture Society 23(1), 23-30. DOI:10.1111/j.17497345.1992.tb00747.x

Gaona, C.A.P., de Almeida, M.S., Viau, V., Poersch, L.H. \& Wasielesky Jr., W. (2017). Effect of different total suspended solids levels on a Litopenaeus vannamei (Boone, 1931) BFT culture system during biofloc formation. Aquaculture Research 48, 1070-1079. DOI: 10.1111/are.12949

Ge, H.X., Ni, Q., Li, J., Li, J.T., Chen, Z. \& Zhao, F.Z. (2018). Integration of white shrimp (Litopenaeus vannamei) and green seaweed (Ulva prolifera) in minimum-water exchange aquaculture system. Journal of Applied Phycology 31(2), 1425-1432. DOI:10.1007/s10811-018-1601-4

George, B., Pancha, I., Desai, C., Chokshi, K., Paliwal, C., Ghosh, T. \& Mishra, S. (2014). Effects of different media composition, light intensity and photoperiod on morphology and physiology of freshwater microalgae Ankistrodesmus falcatus-A potential strain for bio-fuel production. Bioresource Technology 171, 367-374.

Godoy, L.C., Odebrecht,C., Ballester, E., Martins, T.G. \& Wasielesky Jr, W. (2012). Effect of diatom supplementation during the nursery rearing of Litopenaeus vannamei (Boone, 1931) in a heterotrophic culture system. Aquaculture International 20, 559-569. DOI 10.1007/s10499-011-9485-1

Granada, L., Sousa, N., Lopes, S. \& Lemos, M. F. (2016). Is integrated multitrophic aquaculture the solution to the sectors major challenges?-a review. Reviews in Aquaculture 8(3), 283-300. DOI: 10.1111/raq.12093 
Green, B.W., Teichert-Coddington, D.R., Boyd, C.E., Wigglesworth, J.M., Corrales, H.L., Martinez, D. \& McElwee, K. (1999). Influence of daily water exchange volume on water quality and shrimp production. Pond Dynamics/Aquaculture Collaborative Research Support Program, PD/A CRSP, Sixteenth Annual Technical Report, 121-127.

Hadley, S., Wild-Allen, K., Johnson, C. \& Macleod, C. (2015). Modeling macroalgae growth and nutrient dynamics for integrated multi-trophic aquaculture. Journal of Applied Phycology 27(2), 901-916. DOI:10.1007/s10811-014-0370-y

Hargreaves, J.A. (1998). Nitrogen biogeochemistry of aquaculture ponds. Aquaculture 166, 181-212. DOI: 10.1016/S0044-8486(98)00298-1

Hargreaves, J.A. (2006). Photosynthetic suspended-growth systems in aquaculture. Aquacultural Engineering 34, 344-363. DOI: 10.1016/j.aquaeng.2005.08.009

Haslun, J. A., Correia, E., Strychar, K., Morris, T. \& Samocha, T. (2012). Characterization of bioflocs in a no water exchange super-intensive system for the production of food size pacific white shrimp Litopenaeus vannamei. International Journal of Aquaculture 2(1). DOI: 10.5376/ija.2012.02.0006.

He, Q., Zhang, J., Chai, Z., Wu, H., Wen, S. \& He, P. (2014). Gracilariopsis longissima as biofilter for an Integrated Multi-Trophic aquaculture (IMTA) system with Sciaenops ocellatus: Bioremediation efficiency and production in a recirculating system. NISCAIR Publications 528-537.

Hoang, M.N., Nguyen, P.N., Le, D.V., Nguyen, D.V. \& Bossier, P. (2018). Effects of stocking density of gray mullet Mugil cephalus on water quality, growth performance, nutrient conversion rate, and microbial community structure in the white shrimp Litopenaeus vannamei integrated system. Aquaculture 496,

DOI:10.1016/j.aquaculture.2018.07.018

Hoff, F.H. \& Snell, T.W. (2001). Plankton Culture Manual. Florida Aqua Farms Inc., 5th ed., Dade City, FL.

Hopkins J.S. (1994). Elimination of water exchange inintensive shrimp ponds: technology for water qualitymanagement. In: Book of Abstracts (World Aquaculture Society Meeting), pp 30. World Aquaculture Society, Baton Rouge, LA

Huo, Y.Z., Xu, S.N., Wang, Y.Y., Zhang, J.H., Zhang, Y.J., Wu, W.N. \& He, P.M. (2011). Bioremediation efficiencies of Gracilaria verrucosa cultivated in an enclosed sea area of Hangzhou Bay, China. Journal of Applied Phycology 23(2), 173-182. DOI:10.1007/s10811-010-9584-9

Huo, Y., Wu, H., Chai, Z., Xu, S., Han, F., Dong, L. \& He, P. (2012). Bioremediation efficiency of Gracilaria verrucosa for an integrated multitrophic aquaculture system with Pseudosciaena crocea in Xiangshan harbor, China. Aquaculture 326, 99-105. DOI:10.1016/j.aquaculture.2011.11.002

Izzati, M. (2011). The role of seaweeds Sargassum polycistum and Gracilaria verrucosa on growth performance and biomass production of tiger shrimp (Penaeus monodon Fabr). Journal of Coastal Development 14(3), 235-241.

Jackson, C., Preston, N., Thompson, P. J. \& Burford, M. (2003). Nitrogen budget and effluent nitrogen components at an intensive shrimp farm. Aquaculture 218(1-4), 397-411.

Jatobá, A., da Silva, B.C., da Silva, J.S., do Nascimento Vieira, F., Mouriño, J L. P., Seiffert, W.Q. \& Toledo, T.M. (2014). Protein levels for Litopenaeus vannamei in semi-intensive and biofloc systems. Aquaculture 432, 365-371. DOI:10.1016/j.aquaculture.2014.05.005

Joffre, O. M., Poortvliet, P. M. \& Klerkx, L. (2018). Are shrimp farmers actual gamblers? An analysis of risk perception and risk management behaviors among shrimp farmers in the Mekong Delta. Aquaculture 495, 528-537. DOI: 10.1016/j.aquaculture.2018.06.012

Ju, Z.Y., Forster, I.P. \& Dominy, W.G. (2009). Effects of supplementing two species of marine algae or their fractions to a formulated diet on growth, survival, and composition of shrimp (Litopenaeus vannamei). Aquaculture 292(3-4), 237-243. DOI: 10.1016/j.aquaculture.2009.04.040
Juárez-Rosales, J., Ponce-Palafox, J.T., Román-Gutierrez, A.D., OtazoSánchez, E.M., Pulido-Flores, G. \& Castillo-Vargasmachuca, S.G. (2019). Effects of white shrimp (Litopenaeus vannamei) and tilapia nilotica (Oreochromis niloticus var. Spring) in monoculture and co-culture systems on water quality variables and production in brackish low-salinity water earthen ponds during rainy and dry seasons. Spanish Journal of Agricultural Research 17(3), 0605. DOI:10.5424/sjar/2019173-14938

Khatoon H., Banerjee S., Yusoff F.M. \& Shariff M. (2009). Evaluation of indigenous marine periphytic Amphora, Navicula and Cymbella grown on substrate as feed supplement in Penaeus monodon postlarvae hatchery systems. Aquaculture Nutrition 15, 186-193. DOI: 10.1111/j.13652095.2008.00582.x

Khatoon, H., Banerjee, S., Yuan, G.T.G., Haris, N., Ikhwanuddin, M. Ambak, M.A. \& Endut, A. (2016). Biofloc as a potential natural feed for shrimp postlarvae. International Biodeterioration \& Biodegradation 113, 304-309. DOI: 10.1016/j.ibiod.2016.04.006

Krummenauer, D., Samocha, T., Poersch, L., Lara, G. \& Wasielesky, W. (2014). The Reuse of Water on the Culture of Pacific White Shrimp, Litopenaeus vannamei, in BFT System. Journal of the World Aquaculture Society 45(1), 3-14. DOI:10.1111/jwas.12093

Kumar, S., Anand, P.S.S., De, D., Deo, A.D., Ghoshal, T.K., Sundaray, J.K., ... \& Lalitha, N. (2015). Effects of biofloc under different carbon sources and protein levels on water quality, growth performance and immune responses in black tiger shrimp Penaeus monodon (Fabricius, 1978). Aquaculture Research 48(3), 1168-1182. DOI:10.1111/are.12958

Lara, G., Furtado, P.S., Hostins, B., Poersch, L. \& Wasielesky Jr, W. (2016) Addition of sodium nitrite and biofilm in a Litopenaeus vannamei biofloc culture system. Latin American Journal of Aquatic Research 44(4), 760768. DOI:10.3856/vol44-issue4-fulltext-11

Laramore, S., Baptiste, R., Wills, P.S. \& Hanisak, M.D. (2018). Utilization of IMTA-produced Ulva lactuca to supplement or partially replace pelleted diets in shrimp (Litopenaeus vannamei) reared in a clear water production system. Journal of Applied Phycology 30(6), 3603-3610. DOI:10.1007/s10811-018-1485-3

Lavania-Baloo, Azman, S., Said, M. I. M., Ahmad, F. \& Mohamad, M. (2014). Biofiltration potential of macroalgae for ammonium removal in outdoor tank shrimp wastewater recirculation system. Biomass and bioenergy 66, 103-109. DOI:10.1016/j.biombioe.2014.02.031

Lavens, P. \& Sorgeloos, P. (1996). Manual on the production and use of live food for aquaculture. Food and Agriculture Organization (FAO), $\mathrm{n}^{\circ}$ 361.

Lin, C.K., Teichert-Coddington, D.R., Green, B.W., Veverica, K.L. (1997). Fertilization regimes. In: Dynamics of Pond Aquaculture (H.S. Egna \& C.E Boyd, eds.), pp 1-18. CRC Press, Boca Raton, FL.

Lorenzo, M.A., Schveitzer, R., Santo, C.M.E., Candia, E.W.S., Mouriño, J.L.P., Legarda, E.C., Seiffert, W.Q. \& Vieira, F.N. (2015). Intensive hatchery performance of the Pacific white shrimp in biofloc system. Aquacultural Engineering 67, 53-58. DOI: 10.1016/j.aquaeng.2015.05.007

Macchiavello, J. \& Bulboa, C. (2014). Nutrient uptake efficiency of Gracilaria chilensis and Ulva lactuca in an IMTA system with the red abalone Haliotis rufescens. Latin American Journal Aquatic Research 42(3), 523533. DOI: $103856 /$ vol42-issue3-fulltext-12

Magnotti, C., Lopes, R., Derner, R. \& Vinatea, L. (2016). Using residual water from a marine shrimp farming BFT system. part I: nutrient removal and marine microalgae biomass production. Aquaculture Research 47(8), 2435-2443. DOI: 10.1111/are.12691.

Marinho, Y.F., Brito, L.O., Campos, C.V.F.S., Santos, I.G.S. \& Gálvez, A.O. (2014). Effect of addition of Navicula sp. on plankton composition and postlarvae growth of Litopenaeus vannamei reared in culture tanks with zero water exchange. Latin American Journal of Aquatic Research 42(3), 427-437. DOI: 103856/vol42-issue3-fulltext-4 
Marinho, Y.F., Brito, L.O., Campos, C.V.F.S., Severi, W., Andrade, H.A. \& Gálvez, A.O. (2017). Effect of the addition of Chaetoceros calcitrans, Navicula sp. and Phaeodactylum tricornutum (diatoms) on phytoplankton composition and growth of Litopenaeus vannamei (Boone) postlarvae reared in a biofloc system. Aquaculture Research 48, 4155-4164. DOI: 10.1111/are.13235

Marinho-Soriano, E., Azevedo, C.A.A., Trigueiro, T.G., Pereira, D.C., Carneiro, M.A.A. \& Camara, M.R. (2011). Bioremediation of aquaculture wastewater using macroalgae and Artemia. International Biodeterioration \& Biodegradation 65(1), 253-257. DOI: 10.1016/j.ibiod.2010.10.001

Márquez, J.E.Q., Andreatta, E.R., Vinatea, L., Olivera, A. \& Brito, L.O. (2012). Efeito da densidade de estocagem nos parâmetros zootécnicos da criação de camarões Litopenaeus schmitti. Boletim do Instituto de Pesca 38(2), 145-153.

Martinez-Cordova, L.R., Pasten-Miranda, N. \& Barraza-Guardado, R. (1998). Effect of fertilization on growth, survival, food conversion ratio, and production of Pacific white shrimp Penaeus vannamei in earthen ponds in Sonora, Mexico. The Progressive fish-culturist 60(2), 101-108. DOI:10.1577/1548-8640(1998)060<0101:EOFOGS >2.0.CO;2

Martinez-Cordova, L.R., Campaña-Torres, A. \& Porchas-Cornejo, M.A. (2002). The effects of variation in feed protein level on the culture of white shrimp, Litopenaeus vannamei (Boone) in low water exchange experimental ponds. Aquaculture research 33(12), 995-998. DOI: 10.1046/j.13652109.2002.00752.x

Martínez-Cordova, L.R., Emerenciano, M., Miranda-Baeza, A. \& MartínezPorchas, M. (2015). Microbial-based systems for aquaculture of fish and shrimp: an updated review. Reviews in Aquaculture 7, 131-148. DOI: 10.1111/raq.12058

Martins, T.G., Odebrecht, C., Jensen, L.V., D'Oca, M.G. \& Wasielesky Jr, W. (2014). The contribution of diatoms to bioflocs lipid content and the performance of juvenile Litopenaeus vannamei (Boone, 1931) in a BFT culture system. Aquaculture research 47(4), 1315-1326. DOI: $10.1111 /$ are. 12592

Mohanty, R.K., Mishra, A., Panda, D.K. \& Patil, D.U. (2015). Effects of water exchange protocols on water quality, sedimentation rate and production performance of Penaeus monodon in earthen ponds. Aquaculture Research 46(10), 2457-2468.

Moriarty, D.J.W. (1997). The role of microorganisms in aquaculture ponds. Aquaculture 151, 333-349. DOI: 10.1016/S0044-8486(96)01487-1

Ningam, P.S. \& Singh, A. (2011). Production of liquid biofuels from renewable resources. Progress in Energy and Combustion Science 37, 5268. DOI:10.1016/j.pecs.2010.01.003

Niu, J., Xie, J.J., Guo, T.Y., Fang, H.H., Zhang, Y.M., Liao, S.Y. \& Tian, L.X. (2019). Comparison and evaluation of four species of macro-algaes as dietary ingredients in Litopenaeus vannamei under normal rearing and WSSV challenge conditions: effect on growth, immune response, and intestinal microbiota. Frontiers in Physiology 9, 1880. DOI: 10.3389/fphys.2018.01880

Nour, A.A., Zaki, M.A., Abdel-Rahim, M.M. \& Srour, T.M. (2004). Growth performance and feed utilization of marine shrimp Penaeus semisulcatus post-larvae reared in two nursery systems with different stocking sizes. Egyptian Journal of Aquatic Research 30, 390-405.

Nunes, A.J.P., Gesteira, T.C.V. \& Goddard, S. (1997). Food ingestion and assimilation by the southern brown shrimp Penaeus subtilis under semiintensive culture in NE Brazil. Aquaculture 149, 121-136. DOI: 10.1016/S0044-8486(96)01433-0

Ogle, J.T. (1992). Variability in growth of postlarval Penaeus vannamei. Gulf and Caribbean Research 8(4), 423-426.

Omont, A., Elizondo-González, R., Quiroz-Guzmán, E., Escobedo-Fregoso, C., Hernández-Herrera, R. \& Peña-Rodríguez, A. (2020). Digestive microbiota of shrimp Penaeus vannamei and oyster Crassostrea gigas co-cultured in integrated multi-trophic aquaculture system. Aquaculture 521, 735059. DOI:10.1016/j.aquaculture.2020.735059
Otoshi, C.A., Montgomery, A.D., Look, A.M. \& Moss, S.M. (2001). Effects of diet and water source on the nursery production of Pacific white shrimp Litopenaeus vannamei. Journal of the World Aquaculture Society 32(2), 243-249. DOI:10.1111/j.1749-7345.2001.tb01102.x

Øverland, M., Mydland, L.T. \& Skrede, A. (2019). Marine macroalgae as sources of protein and bioactive compounds in feed for monogastric animals. Journal of the Science of Food and Agriculture 99(1), 13-24. DOI: $10.1002 /$ jsfa. 9143

Peixoto Jr, S., Wasielesky Jr, W. \& Louzada Jr, L. (2003). Comparative analysis of pink shrimp, Farfantepenaeus paulensis, and Pacific white shrimp, Litopenaeus vannamei, culture in extreme southern Brazil. Journal of Applied Aquaculture 14(1-2), 101-111. DOI:10.1300/J028v14n01_07

Peña-Rodríguez, A., Magallón-Barajas, F. J., Cruz-Suárez, L. E., Elizondo-González, R. \& Moll, B. (2017). Effects of stocking density on the performance of brown shrimp Farfantepenaeus californiensis co-cultured with the green seaweed Ulva clathrata. Aquaculture Research 48(6), 28032811. DOI:10.1111/are.13114

Perez-Garcia, O. \& Bashan, Y. (2015). Microalgal heterotrophic and mixotrophic culturing for bio-refining: From metabolic routes to technoeconomics. Algal Biorefineries, 61-131. DOI: 10.1007/978-3-319-202006_3

Petersen, J.M., Kemper, A., Gruber-Vodicka, H., Cardini, U., Van Der Geest, M., Kleiner, M. \& Antony, C.P. (2017). Chemosynthetic symbionts of marine invertebrate animals are capable of nitrogen fixation. Nature microbiology 2(1), 16195. DOI: 10.1038/nmicrobiol.2016.195

Poli, M.A., Legarda, E.C., de Lorenzo, M.A., Pinheiro, I., Martins, M.A. Seiffert, W.Q. \& do Nascimento Vieira, F. (2019). Integrated multitrophic aquaculture applied to shrimp rearing in a biofloc system. Aquaculture 511, 734274. DOI:10.1016/j.aquaculture. 2019.734274

Portillo-Clark, G., Casillas-Hernández, R., Servín-Villegas, R. \& Magallón-Barajas, F.J. (2012). Growth and survival of the juvenile yellowleg shrimp Farfantepenaeus californiensis cohabiting with the green feather alga Caulerpa sertularioides at different temperatures. Aquaculture Research 44(1), 22-30. DOI:10.1111/j.1365-2109.2011.03002.x

Rahardjo, S., Soepardjo, A.H., Djokosetiyanto, D., \& Alamsyah, A.T. (2018). Seaweed Utilization for Phytoremediation of Litopenaeus vannamei Shrimp Farming Waste in Recirculation Systems (Environmentally Friendly Design of Sustainable Shrimp Culture). Sustainable Future for Human Security, 145-158. DOI: 10.1007/978-981-10-5430-3_12

Rajkumar, M., Pandey, P.K., Aravind, R., Vennila, A., Bharti, V. \& Purushothaman, C.S. (2016). Effect of different biofloc system on water quality, biofloc composition and growth performance in Litopenaeus vannamei (Boone, 1931). Aquaculture Research 47(11), 3432-3444. DOI:10.1111/are.12792

Ramos, R., Vinatea, L., Santos, J. \& Da Costa, R. (2010). Treatments of effluents from Litopenaeus vannamei shrimp cultures through sedimentation, filtration and absorption. Latin American Journal of Aquatic Research 38(2), 188-200. DOI:10.3856/vol38-issue2-fulltext-3

Ray, A.J., Lewis, B.L., Browdy, C.L. \& Leffler, J.W. (2010). Suspended solids removal to improve shrimp (Litopenaeus vannamei) production and an evaluation of a plant-based feed in minimal-exchange, superintensive culture systems. Aquaculture 299, 89-98. DOI: 10.1016/j.aquaculture.2009.11.021

Ray, A.J., Drury, T.H. \& Cecil, A. (2017). Comparing clear-water RAS and biofloc systems: Shrimp (Litopenaeus vannamei) production, water quality, and biofloc nutritional contributions estimated using stable $\begin{array}{llr}\text { isotopes. Aquacultural } & \text { Engineering 77, } & \text { 9-14. }\end{array}$ DOI:10.1016/j.aquaeng.2017.02.002

Robledo, D., Navarro-Angulo, L., Valdes Lozano, D. \& Freile-Pelegrín, Y. (2012). Nutrient removal efficiency of Hydropuntia cornea in an integrated closed recirculation system with pink shrimp Farfantepenaeus brasiliensis. Aquaculture Research 45(10), 1648-1658. DOI: 10.1111/are.12111 
Rocha, I.P. (2011). Current status and trends in Brazilian shrimp farming. Infofish international, 24-28.

Rodriguez, E.M., Bombeo-Tuburan, I., Fukumoto, S. \& Ticar, R.B. (1993). Nursery rearing of Penaeus monodon (Fabricius) using suspended (hapa) net enclosures installed in a pond. Aquaculture 112(1), 107-111. DOI:10.1016/0044-8486(93)90162-R

Sahni, P., Aggarwal, P., Sharma, S. \& Singh, B. (2019). Nuances of microalgal technology in food and nutraceuticals: a review. Nutrition \& Food Science 49, 866-885. DOI:10.1108/ NFS-01-2019-0008

Sahu, B.C., Adhikari, S. \& Dey, L. (2013). Carbon, nitrogen and phosphorus budget in shrimp (Penaeus monodon) culture ponds in eastern India. Aquaculture International 21(2), 453-466.

Samocha, T.M., Advent, B., Correia, E.S., Morris, T.C. \& Wilkenfeld, J.S. (2010). Growth performance of Litopenaeus vannamei in super intensive mixotrophic raceway culture with zero discharge using Taeration ${ }^{\circledR}$ technology for aeration and extended $\mathrm{CO}_{2}$ degassing. Texas AgriLife Research Mariculture Lab. at Flour Bluff, Corpus Christi, Texas. 45 p. Aquaculture 2010 San Diego, Mar 1-5, 2010.

Samocha, T.M., Schveitzer, R., Krummenaeur, D. \& Morris, T.C. (2012). Recent advances in super-intensive, zero-exchange shrimp raceway systems. Global Aquaculture Advocate 15 (6), 70-71.

Samocha, T.M., Fricker, J., Ali, A.M., Shpigel, M. \& Neori, A. (2015). Growth and nutrient uptake of the macroalga Gracilaria tikvahiae cultured with the shrimp Litopenaeus vannamei in an Integrated Multi-Trophic Aquaculture (IMTA) system. Aquaculture 446, 263-271. DOI: 10.1016/j.aquaculture.2015.05.008

Samocha, T.M., Prangnell, D.I., Hanson, T.R., Treece, G.D., Morris, T.C., Castro, L.F. \& Staresinic, N. (2017). Design and Operation of Super Intensive, Biofloc-Dominated Systems for Indoor Production of the Pacific White Shrimp, Litopenaeus vannamei-The Texas A\&M AgriLife Research Experience. Louisiana: The World Aquaculture Society, 368.

Serra, F.P., Gaona, C.A., Furtado, P.S., Poersch, L.H. \& Wasielesky, W. (2015). Use of different carbon sources for the biofloc system adopted during the nursery and grow-out culture of Litopenaeus vannamei. Aquaculture International 23(6), 1325-1339. DOI:10.1007/s10499-015-9887-6

Schroeder, G.L. (1978). Autotrophic and heterotrophic production of micro-organisms in intensely-manured fish ponds, and related fish yields. Aquaculture 14, 303-325. DOI: 10.1016/0044-8486(78)90014-5

Schveitzer, R., Arantes, R., Costódio, P.F.S., do Espírito Santo, C.M., Arana, L.V., Seiffert, W.Q. \& Andreatta, E.R. (2013). Effect of different biofloc levels on microbial activity, water quality and performance of Litopenaeus vannamei in a tank system operated with no water exchange. Aquacultural Engineering 56, 59-70. DOI: 10.1016/j.aquaeng.2013.04.006.

Schveitzer, R., de Lorenzo, M.A., do Nascimento Vieira, F., Pereira, S.A., Mouriño, J.L.P., Seiffert, W.Q. \& Andreatta, E.R. (2017). Nursery of young Litopenaeus vannamei post-larvae reared in biofloc-and microalgae-based systems. Aquacultural Engineering 78, 140-145. DOI:10.1016/j.aquaeng.2017.07.001

Serfling, S.A. (2006). Microbial flocs: Natural treatment method supports freshwater, marine species in recirculating systems. Global Aquaculture Advocate 6, 34-36.

Shpigel, M., Ari, T.B., Shauli, L., Odintsov, V. \& Ben-Ezra, D. (2016). Nutrient recovery and sludge management in seabream and grey mullet coculture in Integrated Multi-Trophic Aquaculture (IMTA). Aquaculture 464, 316-322. DOI: 10.1016/j.aquaculture.2016.07.007.

Shukri, S. A. \& Surif, M. (2011). The study of biofiltering ability of Gracilaria manilaensisi in reducing inorganic-N waste of shrimp culture. Empowering Science, Technology and Innovation Towards a Better Tomorrow LSP94, 638-643.

Silva, U.L., Campos, S.S. \& Correia, E.D.S. (2008). Efeitos de fertilizantes orgânicos e inorgânicos na abundância de macro e meiobentos e na qualidade da água do cultivo do camarão Litopenaeus vannamei (Boone, 1931). Atlântica 30, 23-33.
Silva, U.L., de Melo, F.P., Soares, R.B., Spanghero, D.B.N. \& de Souza Correia, E. (2009). Efeito da adição do melaço na relação carbono/nitrogênio no cultivo de camarão Litopenaeus vannamei na fase berçário. Acta Scientiarum Biological Sciences 31(4), 337-343. DOI:10.4025/actascibiolsci.v31i4.4496

Silva, K.R., Wasielesky, W. \& Abreu, P.C. (2013). Nitrogen and Phosphorus Dynamics in the Biofloc Production of the Pacific White Shrimp, Litopenaeus vannamei. Journal of the World Aquaculture Society 44(1), 30-41. DOI: 10.1111/jwas.12009

Skriptsova, A.V. \& Miroshnikova, N.V. (2011). Laboratory experiment to determine the potential of two macroalgae from the Russian Far-East as biofilters for integrated multi-trophic aquaculture (IMTA). Bioresource technology 102(3), 3149-3154. DOI:10.1016/j.biortech.2010.10.093

Smith, D.M., Burford, M.A., Tabrett, S.J., Irvin, S.J. \& Ward, L. (2002). The effect of feeding frequency on water quality and growth of the black tiger shrimp (Penaeus monodon). Aquaculture 207(1-2), 125-136. DOI: 10.1016/S0044-8486(01)00757-8

Southgate, P.C. \& Lucas, J.S. Principles of Aquaculture. (2019). In: Aquaculture: Farming Aquatic Animals and Plants (J.S. Lucas, P.C. Southgate \& C.S. Tucker, eds.), pp 19-23. John Wiley \& Sons, West Sussex, UK.

Souza, F.M.M.C., Messias, G.A., Fialho, D.H.F., Soares, R.B. \& de Souza Correia, E. (2009). Crescimento do camarão marinho Farfantepenaeus subtilis (Pérez-Farfante, 1967) cultivado em tanques com diferentes protocolos de fertilização orgânica. Acta Scientiarum Biological Sciences 31(3), 221-226. DOI: 10.4025/actascibiolsci.v31i3.7565

Souza, S.M.G., Mathies, V.D. \& Fioravanzo, R.F. (2012). Off-flavor by geosmine and 2-methylisoborneol in aquaculture. Ciências Agrárias 33, 835-846. DOI: 10.5433/1679-0359.2012v33n2p835

Souza, D.M., Suita, S.M., Romano, L.A., Wasielesky Jr, W. \& Ballester, E.L.C. (2014). Use of molasses as a carbon source during the nursery rearing of Farfantepenaeus brasiliensis (Latreille, 1817) in a Biofloc technology system. Aquaculture Research 45(2), 270-277. DOI:10.1111/j.13652109.2012.03223.x

Supono, S., Hutabarat, J. \& Prayitno, S.B. (2014). White Shrimp (Litopenaeus vannamei) Culture using Heterotrophic Aquaculture System on Nursery Phase. International Journal of Waste Resources 4(2), 1-4.

Tabarsa, M., Rezaei, M., Ramezanpour, Z. \& Waaland, J.R. (2012). Chemical compositions of the marine algae Gracilaria salicornia (Rhodophyta) and Ulva lactuca (Chlorophyta) as a potential food source. Journal of the Science of Food and Agriculture, 92(12), 2500-2506. DOI: $10.1002 /$ jsfa.5659.

Tacon, A.G.J., Nates, S.F. \& Mcneil, R.J. (2004). Dietary feeding strategies for marine shrimp: a review. In: Avances en nutrición Acuícola (L.E. Cruz Suárez et al., eds.). Memorias del VII Simposium Internacional de Nutrición Acuícola, Sonora, Mx.

Taw, N., \& Chandaeng, S. (2005). The role of R\&D and commercial trials on efficiency and productivity of large integrated shrimp farm. Paper presented at World Aquaculture 2005, May 9-13, Nusa Dua, Bali, Indonesia. Book of Abstracts, 643.

Taw, N., Poh, Y. T., Ling, T. M., Thanabatr, C. \& Salleh, K. Z. (2011). Malaysian shrimp farm redesign successfully combines biosecurity, biofloc technology. Global Aquaculture Advocate, 74-75.

Troell, M., Joyce, A., Chopin, T., Neori, A., Buschmann, A.H. \& Fang, J.G. (2009). Ecological engineering in aquaculture - Potential for integrated multi-trophic aquaculture (IMTA) in marine offshore systems. Aquaculture 297(1-4), 1-9. DOI: 10.1016/j.aquaculture.2009.09.010

Viadero, R.C., Cunningham, J.H., Semmens, K.J. \& Tierney, A.E. (2005). Effluent and production impacts of flow-through aquaculture operations in West Virginia. Aquacultural Engineering 33(4), 258-270. DOI: 10.1016/j.aquaeng.2005.02.004 
Vinatea-Arana, L. (2004). Princípios Químicos de Qualidade da Água em Aqüicultura: uma revisão para peixes e camarões. (Chemical Principles of Water Quality in Aquaculture: a review for fish and shrimp). UFSC Publisher, 231 pp. UFSC Publisher, 2nd ed., Florianópolis, BR.

Wasielesky, W., Atwood, H., Stokes, A. \& Browdy, C.L. (2006). Effect of natural production in a zero exchange suspended microbial floc based super-intensive culture system for white shrimp Litopenaeus vannamei. Aquaculture 258, 396-403. DOI: 10.1016/j.aquaculture.2006.04.030

Wasielesky Jr, W., Abreu, P.C., Poersch, L.H., Thompson, F. \& Ballester, E.L.C. (2012). Influence of light intensity on biofilm formation and the performance of pink shrimp Farfantepenaeus paulensis juveniles reared in cages. Aquaculture research 43(5), 706-712. DOI:10.1111/j.13652109.2011.02878.x

Wasielesky, W., Krummenaeur, D., Lara, G., Fóes, G. \& Poersch, L. (2013). Cultivo de camarões em sistema de bioflocos: realidades e perspectivas. (Shrimp cultivation in a biofloc system: realities and perspectives). ABCC Magazine 15 (2), 30-36.

Wheeler, A.P. \& Kirchman, D.L. (1986). Utilization of inorganic and organic nitrogen by bacteria in marine systems. Limnology and Oceanography 31, 998-1009. DOI: 10.4319/lo.1986.31.5.0998

Wyban, J.A., Lee, C.S., Sato, V.T., Sweeney, J.N. \& Richards Jr, W.K. (1987). Effect of stocking density on shrimp growth rates in manure-fertilized ponds. Aquaculture 61(1), 23-32. DOI: 10.1016/0044-8486(87)90334-6

$\mathrm{Xu}$, W.J. \& Pan, L.Q. (2014). Dietary protein level and C/N ratio manipulation in zero-exchange culture of Litopenaeus vannamei: Evaluation of inorganic nitrogen control, biofloc composition and shrimp performance. Aquaculture Research 45(11), 1842-1851. DOI:10.1111/are.12126

Xu, W.J., Morris, T.C. \& Samocha, T.M. (2016). Effects of C/N ratio on biofloc development, water quality, and performance of Litopenaeus vannamei juveniles in a biofloc-based, high-density, zero-exchange, outdoor tank system. Aquaculture 453, 169-175. DOI: 10.1016/j.aquaculture.2015.11.021

Xu, W J., Morris, T.C. \& Samocha, T.M. (2018). Effects of two commercial feeds for semi-intensive and hyper-intensive culture and four $\mathrm{C} / \mathrm{N}$ ratios on water quality and performance of Litopenaeus vannamei juveniles at high density in biofloc-based, zero-exchange outdoor tanks. Aquaculture 490, 194-202. DOI:10.1016/j.aquaculture.2018.02.028

Yusoff, I., Hiscock, K.M. \& Conway, D. (2002). Simulation of the impacts of climate change on groundwater resources in eastern England. Geological Society 193, 325-344. DOI: 10.1144/GSL.SP.2002.193.01.24 